\title{
REVIEW
}

\section{Porcine pluripotent stem cells: progress, challenges and prospects}

\author{
Jianyong HAN ${ }^{1 *}$, Yi-Liang MIAO ${ }^{2 *}$, Jinlian $\mathrm{HUA}^{3 *}$, Yan $\mathrm{LI}^{4}$, Xue ZHANG ${ }^{4}$, Jilong $\mathrm{ZHOU}^{2}$, Na $\mathrm{LI}^{3}$, \\ Ying ZHANG ${ }^{3}$, Jinying ZHANG ${ }^{1}$, Zhonghua LIU (ه) $)^{4}$ \\ 1 State Key Laboratory for Agrobiotechnology, College of Biological Sciences, China Agricultural University, Beijing 100193, China \\ 2 Institute of Stem Cell and Regenerative Biology/College of Animal Science and Veterinary Medicine/Key Laboratory of Agricultural \\ Animal Genetics Breeding and Reproduction of Ministry of Education, Huazhong Agricultural University, Wuhan 430070, China \\ 3 College of Veterinary Medicine/Shaanxi Centre of Stem Cells Engineering and Technology, Northwest A\&F University, \\ Yangling 712100, China \\ 4 Key Laboratory of Animal Cellular and Genetic Engineering of Heilongjiang Province, College of Life Science, Northeast Agricultural \\ University, Harbin 150030, China
}

\begin{abstract}
Pluripotent stem cells (PSCs) are characterized by their capacity for high self-renewal and multiple differentiation potential and include embryonic stem cells, embryonic germ cells and induced PSCs. PSCs provide a very suitable model for the studies of human diseases, drugs screening, regenerative medicine and developmental biology research. Pigs are considered as an ideal model for preclinical development of human xenotransplantation, therapeutic approaches and regenerative medicine because of their size and physiological similarity to humans. However, lack of knowledge about the derivation, characterization and pluripotency mechanisms of porcine PSCs hinders progress in these biotechnologies. In this review, we discuss the latest progress on porcine PSCs generation, evaluation criteria for pluripotency, the scientific and technical questions arising from these studies. We also introduce our perspectives on porcine PSC research, in the hope of providing new ideas for generating naive porcine PSCs and animal breeding.
\end{abstract}

Keywords embryonic germ cells, embryonic stem cells, induced pluripotent stem cells, pigs, pluripotent stem cells

\section{Introduction}

Pluripotent stem cells (PSCs) are characterized by their developmental competence to give rise to properties of all three germ layers, including germ cells, but excluding the extra-embryonic tissues. Three types of PSCs have been

Received January 10, 2018; accepted March 29, 2018

Correspondence: liuzhonghua@neau.edu.cn

${ }^{*}$ These authors contribute equally to the work reported: embryonic stem cells (ESCs), which are derived from the inner cell mass (ICM) of blastocysts and conform to the general standards of pluripotency; embryonic germ cells (EGCs) from primordial germ cells and induced PSCs (iPSCs), which are derived from differentiated cells with forced expression of selected transcription factors. Since PSCs have capabilities of in vitro self-renewal and competence for development of three germ layers both in vivo and in vitro, they are regarded as a powerful model for functional genomics research, and hold great potential in cell transplantation pharmacy, human genetic disease treatment and livestock breeding.

Pigs are important farm animals and also one of the best candidates for human disease models and as xenotransplantation donors because of their well-known similarities to humans in organ size as well as morphology and physiology. The establishment of porcine PSC lines can facilitate the application of pig cells in both biomedical and agricultural fields, especially for the evaluation of efficiency and safety of stem cell related therapies in human. Although great progress on mouse and human PSCs has been achieved in recent decades, research on PSCs in pigs and other large animals has encountered huge difficulties, and there are no porcine PSC lines available that fulfill all the characteristics of mouse ESCs, especially the germline chimeras. This situation indicates that the exploration of PSCs from pig and other large animals has significant theoretical importance for understanding the specific regulation of pluripotency in different species.

In this review, we summarize progress on the derivation of pig ESCs, EGCs and iPSCs, discuss the methods for evaluation of the pluripotency of porcine PSCs, analyze the challenges to the generation of naive porcine PSCs and provide a perspective for future studies. 


\section{Derivation of porcine embryonic stem cells}

Great effort has been expended to derive porcine ESCs (pESCs) since the first report by Evans and Kaufman ${ }^{[1]}$ in 1990 due to their promising potential in both biomedical and agricultural fields. Although pESC-like cell lines that satisfy general pluripotency criteria have been reported, including the capability of extensive self-renewal, expression of alkaline phosphatase (AP), OCT4 (also named $P O U 5 F 1)$ and a panel of other markers, as well as the ability to differentiate into derivatives of all three germ layers in vitro and in teratomas, there have been few reports of the development of these pESC-like cells into germline chimeras. Furthermore, according to the definition of mouse ESCs, pESCs have not been successfully produced that show the complete characteristics of the naive state.

ESCs have been considered to arise as a result of a selective adaptation process to the culture conditions and to be an artifact rather than a physiological cell type ${ }^{[2]}$ and considerably greater attention needs to be paid to the optimization of in vitro culture conditions to acquire pESCs.

\subsection{Embryo stage for establishing pESCs}

Embryo development stage is an important factor for ESCs derivation. By comparison between human and mouse embryos, the porcine embryo is unique due to its extended preimplantation development. Studies on preimplantation embryo development indicate that the compaction of blastomeres happens around days 4-5 post in vitro fertilization or the last in vivo insemination, and blastocysts develop with clearly differentiated ICM and trophectoderm (TE) around days $5-6^{[3]}$. OCT4, one of the key transcription factors governing pluripotency, is expressed in both ICM and TE of porcine embryos, and this expression pattern clearly differs from that of mouse embryos ${ }^{[4]}$. GATA6 ${ }^{[4]}$ and Vimentin ${ }^{[5]}$ begin to be expressed in some of the cells in ICM on days 8 and 9 , respectively, which indicates the initiation of the further differentiation of ICM. The species-specific developmental pattern of porcine preimplantation embryos makes it difficult to identify the appropriate developmental stage to use to derive pESCs from the approaches used to produce mouse and human ESCs.

Porcine preimplantation embryos at different developmental stages have been used to establish pESCs, but the results from different researchers are not consistent. Days 7-9 blastocysts were used by Evans et al. ${ }^{[6]}$ in the first reported attempts to derive pESCs, and ESC-like cell lines were derived from these blastocysts. In contrast with this result, ESC-like cell lines or ESC-like colonies that could survive for more than a few passages have generally been derived from expanding or hatched blastocysts, although the day ranges for collection of the blastocysts varied from days $5-9^{[7-10]}$. Pre-compaction embryos and morulae have also been used to derive pESCs, but the attachment rates of these embryos were low and none of the embryos began outgrowt $^{[11]}$. Moreover, it has been reported that hatched blastocysts and elongating blastocysts around days 10-11 have been used to derive $\mathrm{pESCs}^{[12]}$ and ESC-like colonies could be derived from $50 \%$ of the isolated embryonic discs and could be maintained in culture for at least 8 weeks, while only a few ESC-like colonies were derived from days 5-6 blastocysts in this study. Chen et al ${ }^{[8]}$ collected days $6-8$ porcine embryos for derivation of pESCs. They classified the collected embryos into morulae, early blastocysts, expanding blastocysts, early hatched blastocysts, intermediate hatched blastocysts and late hatched blastocysts according to morphology, and found two types of ESC-like colonies formed from early hatched blastocysts, which were called type A and B. Only type B colonies were isolated from ICM of late hatched blastocysts, and no colonies survived more than five passages in the morulae group. One cell line derived from type A colonies generated a chimeric piglet with overt pigmentation chimerism, although this chimeric piglet did not show germline chimerism, which was suggested by the limited offspring. In contrast with these results, Xue et al. ${ }^{[10]}$ reported ESC-like cell lines derived from expanding to early hatched embryos. The reported ESClike cells could survive more than 75 passages and retained their pluripotent characteristics and normal karyotype after transfection with fluorescent protein gene DsRed. These ESC-like cells could contribute to the chimeric development of both ICM and TE in expanding blastocysts and chimeric development of both fetus and placenta to day 50 gestation.

It is difficult to ascertain which developmental stages of porcine embryos are appropriate to use to derive pESCs because there is a lack of consistency in these reports. The post estrus and insemination dates for in vivo embryos or post fertilization for in vitro embryos are not an accurate criterion to define the developmental stages because the developmental speed of embryos from the same in vivo ovulation or in vitro fertilization is different and results in embryos with different morphologies at the same time point. Embryo morphology is an alternative criterion for determination of the developmental stages and it has advantages for comparing embryos employed in different studies. According to the morphology criteria, expanding and early hatched blastocysts might be considered first for derivation of pESCs because most of the reported ESC-like cells lines were derived from these two developmental stages regardless of the day of development ${ }^{[7-10]}$. Also, this suggestion is supported by the results on expression of genes associated with pluripotency in preimplantation embryos $^{[4,13-16]}$.

Other considerations related to selection of embryos for derivation of pESCs include the origin of the embryos and 
the methods for seeding. Progress on these two topics has been comprehensively reviewed ${ }^{[17,18]}$, so they will not be discussed in this review. The relationship between stages of embryo development and derivation of PSC in mice, humans and pigs are summarized in Fig. 1.

\subsection{Development of culture conditions}

ESCs derived from embryos are not identical to the pluripotent blastomeres, ICM cells or epiblast cells. To a certain extent, the biological characteristics of ESCs depend on culture conditions. The conversion of mouse EpiSCs into ESCs in 2i/LIF culture system and the conversion of mouse ESCs to expanded PSCs (EPSC), or vice versa, provides clear evidence for the importance of culture conditions $^{[19-22]}$. Compared to the large number of studies examining appropriate culture conditions for mouse and human ESCs, minimal data are available for ESCs culture conditions of domestic animals ${ }^{[23]}$. In the early years, ESC cultural conditions were developed mainly for mouse $\mathrm{ESCs}^{[6,24,25]}$ and then human ESC culture systems were carefully studied ${ }^{[10,26]}$. Generally, the culture medium consists of Dulbecco's Modified Eagle's Medium (DMEM) supplemented with 2-mercapthoethanol, L-glutamine, antibiotics, nucleosides, non-essential amino acids, fetal bovine serum (FBS) and different cytokines, and alternative components. For the basic medium, variations of DMEM from high glucose to low

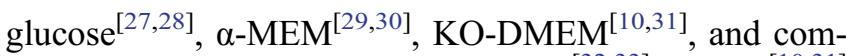
binations of DMEM with Ham's-F10 ${ }^{[32,33]}$ or F12 $2^{[10,31]}$ have been examined. The results from different studies are not consistent, but pESC-like cell lines have predominantly been derived from DMEM medium without consideration of glucose concentrations. FBS has an important but contradictory role in the derivation of pESCs. It is believed that FBS contributes positively to the attachment of embryos to feeder layers and the derivation of outgrowths, but it is also the main source of potential differentiating factors in ESC culture. Defined serum-free replacement (KOSR) was introduced to replace FBS for further improved ESC cultures, and there are increasing reports on the use of KOSR for pESC derivation $^{[10,27,34]}$.

The feeder layer is a fundamental feature for ESC cultures. It is generally believed that the feeder layer provides an attachment matrix for the seeded embryos, the subsequent outgrowth and passaged cells, cytokines such as leukemia inhibitory factor (LIF) to stimulate cell proliferation and inhibit cell differentiation. The wide use of feeder layer conditioned medium indicates the great importance of feeder layers for the release of specific factors and the attachment ability of the matrix and the evidence indicates that little success could be achieved from feeder-layer-free culture systems ${ }^{[32,35]}$. Although there are reports about the effects of different feederlayer cells on pESCs derivation ${ }^{[7,9,12,24]}$, STO cell lines or
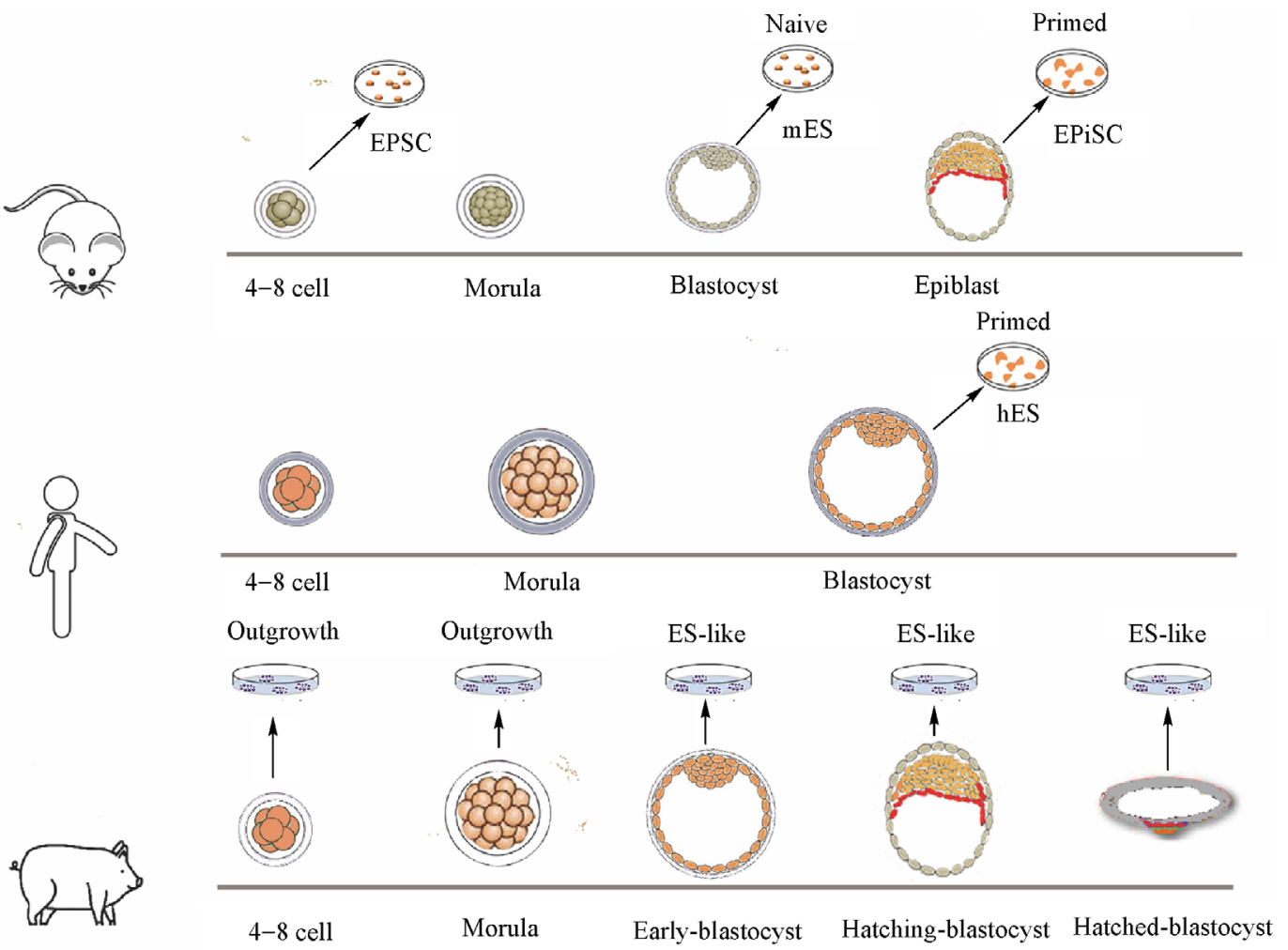

Fig. 1 Derivation of pluripotent stem cells from different embryo development stage 
mouse embryonic fibroblasts are normally used as feeder cell layers because they are easy to prepare and have comparatively few variations in biological characteristics (Table 1).

LIF and basic fibroblast growth factor (bFGF) are two cytokines that have been clearly demonstrated to be crucial for regulating networks of mouse and human ESCs, respectively. There are still debates concerning the exact function of LIF and bFGF in pESCs cultures, although results from different reports indicate that both LIF and bFGF can exert a positive influence on the survival, proliferation and self-renewal of $\mathrm{pESCs}^{[9,26,31,34]}$. The function of LIF and bFGF on the pESC-like cell culture has been examined and the results showed that LIF is dispensable for cell survival, and bFGF is necessary for inhibition of cell differentiation ${ }^{[10]}$. Some other cytokines have also been examined for their potential benefit for the derivation of $\mathrm{pESCs}$, such as transforming growth factorbeta $(\mathrm{TGF}-\beta)^{[43]}$, epidermal growth factor ${ }^{[43]}$ and stem cell factor $(\mathrm{SCF})^{[43]}$, however, these factors did not have any obvious effects on porcine stem cells.

Great attention is paid to small molecules in the study of ESCs because of their success in derivation of rat and mouse ESCs from the so-called non-permissive NOD strain. This has been further strengthened by the reports on ciPS and expanded PSCs (EPSCs), in which small molecules were carefully screened and combinations of selected small molecules were used to derive iPSCs from differentiated somatic cells without introducing transcription factors into cells ${ }^{[21,44]}$ or EPSCs from precompaction embryos $^{[22]}$. Reports on these small molecules have included glycogen synthase kinase 3 beta inhibitor CHIR99021 (CH), Erk signaling inhibitor PD184352 $(\mathrm{PD})^{[45]}$ and KLF4 substitute Kenpaullone (KP) ${ }^{[46]}$, and showed that mouse ESC-like cell lines can be derived from porcine embryos, and some cell lines can be cultured continuously over 100 passages without any overt morphological changes, which indicates these small molecules have great values for the derivation of pESCs. However, there are also contradictory reports on the effects of these small molecules when employed in pESCs cultures $^{[45,47]}$. It is clear that small molecules have shown great potential for derivation of ESCs, and intensive screening is needed to achieve optimal concentrations and combinations of the small molecules to support authentic pESCs derivation.

\section{Pluripotent stem cells derived from germlines}

3.1 Derivation of pluripotent stem cells from primordial germ cells

Primordial germ cells (PGCs) are embryonic cells that migrate from the root of the allantois to the genital ridge, where they ultimately give rise to gametes ${ }^{[48]}$. PGCs do not belong to the stem cell population at any stage during embryonic development, but they can indefinitely proliferate under certain in vitro culture conditions and generate a PSC population. Using component defined culture systems, porcine PGCs derived from 24 to $28 \mathrm{dpc}$ genital ridge can proliferate steadily and are known as embryonic germ cells $(\mathrm{EGCs})^{[41,49]}$. In 1992, it was first reported that mouse unipotent PGCs can be converted into $\mathrm{EGCs}^{[36,50]}$. Subsequent research also demonstrated that EGCs could be established from human PGCs ${ }^{[39]}$. EGCs share several important characteristics with ESCs, including their morphology, pluripotency and capability of contributing to germline chimeras when injected into blastocysts ${ }^{[1,52]}$.

Unlike ESCs, EGCs are inseparable from the feeder cell type. Growth factors including LIF, bFGF and SCF are essential for the derivation of porcine $\mathrm{EGCs}^{[39]}$. PGCs could be reprogrammed into iEGCs using small molecules and transcription factors of OCT4 and C-MYC ${ }^{[53]}$. In addition, hypoxia induces reprogramming of PGCs by deregulating expression of $O C T 4^{[54]}$. In human PGCs, the expression of endogenous $K L F 4$ and $C-M Y C$ is similar to EGCs, but the expression levels of SOX2 and OCT4 are lower than EGCs. Thus, the reprogramming of PGCs into iPSCs can occur only by employing two transcription factors, SOX2 and $O C T 4^{[55]}$. Only one study has found that

Table 1 Pluripotent stem cells derived from primordial germ cells

\begin{tabular}{|c|c|c|c|c|}
\hline Species & Cell source & Culture system & Differentiation potential & Reference \\
\hline$\overline{\text { Mouse }}$ & $\begin{array}{c}\text { 8.5 dpc PGCs } \\
7.0 \mathrm{dpc} \text { PGCs } \\
11.5-13.5 \mathrm{dpc} \text { PGCs }\end{array}$ & $\begin{array}{c}\text { STO feeder layer + SCF, LIF, bFGF } \\
\text { STO feeder layer + SCF, LIF, bFGF } \\
\text { MEF feeder layer + LIF, SB431542, Kempaullone }\end{array}$ & $\begin{array}{c}\text { Chimera } \\
\text { ES-like cells, teratomas } \\
\text { Chimera }\end{array}$ & $\begin{array}{l}{[36]} \\
{[37]} \\
{[38]}\end{array}$ \\
\hline Human & $\begin{array}{l}\text { 5-9 weeks PGCs } \\
106 \text { dpc PGCs } \\
\text { 4-13 week PGCs }\end{array}$ & $\begin{array}{c}\text { STO feeder layer + LIF, bFGF, Forskolin } \\
\text { DMEM + 10\% NBS } \\
\text { Knockout DMEM }+20 \mathrm{KSR}+\mathrm{LIF}+\mathrm{bFGF}+\text { Forskolin }\end{array}$ & $\begin{array}{l}\text { EG-like cells, all three germ layer } \\
\text { cells } \\
\text { ES-like cells } \\
\text { ES-like cells, all three germ layer } \\
\text { cells }\end{array}$ & $\begin{array}{l}{[39]} \\
{[40]}\end{array}$ \\
\hline Porcine & $\begin{array}{l}\text { E25-27 PGCs } \\
\text { E25-27 PGCs }\end{array}$ & $\begin{array}{c}\text { STO feeder }+\mathrm{SCF}+\mathrm{bFGF}+\mathrm{LIF} \\
\text { Using a growth-factor-defined culture system supple- } \\
\text { mented bFGF }\end{array}$ & $\begin{array}{c}\text { ND } \\
\text { Chimera }\end{array}$ & $\begin{array}{l}{[41]} \\
{[42]}\end{array}$ \\
\hline
\end{tabular}


a porcine iPSC line could be established by transfecting six human reprogramming factors (OCT4, SOX2, NANOG, $K L F 4, L I N 28$ and $C-M Y C$ ) which possessed the ability to produce chimeric offspring ${ }^{[42]}$ (Table 1). However, there have been no subsequent reports on the production of porcine chimeras. Most iPSC lines fulfilled the criteria of pluripotency, but the cells could not contribute to chimeras or generate cloned piglets ${ }^{[56-60]}$.

\subsection{Derivation of pluripotent stem cells from testis}

Spermatogonia stem cells (SSCs) are the only type of stem cells in the body that transmits genetic information to offspring ${ }^{[61,62]}$. They can continuously generate differentiating spermatogonia ${ }^{[63]}$. Generally it is considered that $\mathrm{SSCs}$ are equal to A-single (As) cells. However, the number of SSCs qualified by transplantation is only $0.002 \%$, which indicates that not all As spermatogonia function as SSCs ${ }^{[64]}$. To date, SSCs are the only adult stem cells showing significant OCT4 expression, which is a specific marker for pluripotent and germ cells. The role of OCT4 in germ cell development was elucidated by the demonstration that knockout of this gene led to apoptosis $^{[65,66]}$. During the SSCs culture process, germline stem cell (GSC) clones could be observed, which were typically grape-like clusters $^{[67]}$ (Table 2). Using neonatal Sertoli cells as the feeder and DMEM/F-12 culture medium supplemented with $10 \% \mathrm{KSR}$ and four cytokines, the undifferentiated spermatogonia could proliferate in vitro for at least 2 months without loss of stemness ${ }^{[67]}$. Our preliminary study demonstrated that Peptide-coating 2D is beneficial to the long-term culture of porcine male germ cell-derived clones (pGDCs), and lipid seems effective in prolonging the culture time of pGDCs in vitro (unpunished data of Jinlian Hua research group). In addition, germlinederived PSCs (gPSCs) can be observed with a low frequency under certain culture conditions for both mouse and human cells ${ }^{[69-72]}$, being morphologically similar to mouse ESCs. These ESC-like cells were phenotypically similar to ESCs/GSCs except for their genomic imprinting pattern. Kossack et al. ${ }^{[69]}$ found that conversion of GSCs into gPSCs did not alter their imprinting status. gPSCs did not result in the birth of pups after tetraploid complementation $(0 / 82)$, which was likely due to the imprinting status of gPSCs, whose DMRs of H19 and ICRs of Igf2r are maintained as androgenetic patterns. This result was also supported by a report showing that DNA methylation of imprinted genes is critical for fetal development ${ }^{[73]}$. It is important to note that paternal imprinting patterns of $\mathrm{H} 19$ and Igf2r in gPSCs are not altered, even after 20 passages. Unlike PSCs from the testis of newborns ${ }^{[74]}$, gPSCs from adult GSCs still maintained an androgenetic pattern in DMRs of H19. Furthermore, these ESC-like cells formed chimeras when injected into blastocysts ${ }^{[74,75]}$. All these studies support the notion that, compared to somatic cells, germ cells have the distinct potential to be converted into ESC-like stages without the introduction of exogenous reprogramming factors $^{[69]}$. The molecular mechanisms underlying the natural shift from a unipotent to a completely pluripotent cell during the establishment of mouse ESC-like cells from SSCs are not yet completely understood ${ }^{[76]}$. However, in cultures with growth factors, the cell density of SSCs during culture, the time period after initiation of the culture, and the length of the culture might all be key factors in the transition process ${ }^{[77-80]}$. Furthermore, this phenomenon seems to be age-dependent. Several studies of long-term cultivation for SSCs failed to prevent this spontaneous shift of SSCs to pluripotent ESC-like cells $^{[81,82]}$.

\subsection{Derivation of pluripotent stem cells from ovary}

Female GSCs (FGSCs) isolation from neonatal and adult mice and long-term culture have attracted considerable interest in stem cell biology ${ }^{[83,84]}$. FGSCs have been isolated independently by at least two research groups and from a number of species (human, mouse and rat). Wang et al. ${ }^{[85]}$ found that stably proliferating FGSCs from neonatal or prepubertal mouse ovaries can be converted to female ESC-like cells within one month under ESCs culture conditions. These cells exhibited ESC-like characteristics such as ESCs morphology, expression of pluripotency markers and had a normal karyotype. Also, they could differentiate into the three germ layers in vitro, form teratomas in vivo and contribute to chimeras and the germline (Table 3). Dissected cells from porcine thecal layers maintained similar characteristics to mouse FGSCs

Table 2 Pluripotent stem cells derived from testis

\begin{tabular}{lcccc}
\hline Species & Cell source & Culture system & Differentiation potential & Reference \\
\hline Mouse & Neonatal testis & MEF feeder layer + standard ESCs culture conditions & Chimera & [68] \\
Human & Testicular cells & hESCs culture conditions & All three germ layers, no teratoma & [69] \\
Porcine & Neonatal testicular cells & DMEM/F-12 $+10 \%$ KSR and four cytokines & Colonize in vivo and differentiate & [67] \\
\hline
\end{tabular}

Table 3 Pluripotent stem cells derived from mouse ovary

\begin{tabular}{cccc}
\hline Cell source & Culture system & Differentiation potential & Reference \\
\hline Neonatal mouse ovary cells & ESCs culture conditions & All three germ layers, Teratomas, Chimera (dead) & {$[85]$} \\
\hline
\end{tabular}


and ESCs over 4 months of in vitro culture. At present, however, controversy remains over the biological significance of these cells.

\section{Induced pluripotent stem cells}

\subsection{Overview and progress on induced pluripotent stem cells}

iPSCs with a gene expression profile and developmental potential similar to embryonic stem cells can be generated from mouse somatic cells using a cocktail of four transcription factors ${ }^{[86]}$, and the four factors OCT4, SOX2, KLF4 and $C-M Y C$, called Yamanaka factors ${ }^{[87]}$. The generation of iPSCs with OSKM has been described as direct reprogramming in contrast to reprogramming via nuclear transfer. Chimeric mice produced by microinjection of iPSCs into a blastocyst ${ }^{[88]}$ and iPSC-mouse generated by tetraploid complementation, suggest that the pluripotency of these cells is equivalent to that of ESCs cells $^{[89]}$.

\subsection{Progress on inducing pluripotent stem cells of pig and other large animals}

Lines of iPSCs have been generated from some domesticated ungulates, such as sheep ${ }^{[90,91]}$, pigs $^{[87,92,93]}$ and cattle ${ }^{[94,95]}$. Porcine iPSCs have been produced in many laboratories using various induction methods and show pluripotency to some degree ${ }^{[59,93,96,97]}$. Porcine iPSCs could pass the test of germline chimera production at the molecular genotyping levels using $\mathrm{PCR}^{[42,98]}$, but stable chimerism remains to be determined. Thus far, porcine iPSCs have not been shown to pass the crucial test of authentic pluripotency by generation of all-iPSC pigs through tetraploid embryo complementation.

Although iPSC technology has great potential for clinical application, its safety has attracted extensive attention ${ }^{[99]}$. Until recently, most of iPSCs were generated using integrating retroviral vectors, but the persistent expression of exogenous genes raises the risk of cancer, if it is not silenced ${ }^{[100,101]}$. Additionally, the residual expression of exogenous factors may interfere with the normal differentiation function of iPSCs and affect their ability to form chimeras ${ }^{[100,102,103]}$. Before using iPSCs clinically, the inserted transgenes have to be either deleted or effectively silenced after the cells have been reprogrammed. With other approaches, for example using nonintegrating vectors ${ }^{[104,105]}$, introduction of stemness proteins ${ }^{[106,107]}$, or pharmaceutically with a suitable combination of small molecules, have been developed to address this problem to a certain extent ${ }^{[44,108,109]}$. Recently, a new method to generate iPSCs with CRISPR activation through precise epigenetic remodeling of endogenous loci shed light on how targeted chromatin remodeling triggers pluripotency induction ${ }^{[110]}$.

Authentic porcine iPSCs cannot survive in culture following the silencing or downregulation of the reprogramming factors. The key signaling pathways in pig, mouse and human iPSCs indicate that the core transcriptional network necessary for maintaining pluripotency and self-renewal in pig is different from that in mouse but has significant similarities to human iPSCs ${ }^{[111]}$. The current transcriptome data confirmed that the JAK-STAT3 signaling pathways were not fully activated in porcine iPSCs due to the lack of a LIF receptor, but porcine iPSCs are unable to maintain self-renewal soon after LIF withdrawal ${ }^{[112,113]}$, while LIF-based cell medium with specific protein kinase inhibitors can sustain porcine iPSCs in the mESC state ${ }^{[111]}$. Therefore, understanding the key signaling pathways that regulate cell renewal in porcine pluripotent cells may help improve culture conditions and allow for establishment of stable porcine iPSCs. The identification of culture conditions of pluripotent cells from livestock would accelerate biological research in these species and enhance their utility as animal models.

\section{Criteria for evaluating pluripotency in porcine stem cells}

It is important to establish good criteria to evaluate the pluripotency of porcine stem cells. Most evaluation criteria for porcine PSCs are based on those used for mouse PSCs. We summarize below the methods used to evaluate the pluripotency of porcine stem cells in recent decades.

\subsection{Morphological parameters}

\subsubsection{Morphology of stem cells}

Most porcine PSCs have an epithelial-like colony morphology (Tables 4-6), which is very similar to human ESCs or mouse epiblast stem cells (EpiSCs) ${ }^{[29,115,121,138,147,148]}$. They show a large, flat and round (polygonal in rare cases) shape with compact colonies and distinct borders, with relatively small diameters and a high nucleus-to-cytoplasm ratio, a single nucleus with multiple nucleoli, and are sensitive to tryptase. These cells grow more slowly and have limited capability to be integrated into host blastocysts $^{[92,120,122,134,141,143]}$. Another type of porcine PSCs was shown to have a mouse ESCs morphology, i.e., small, not flat and with a compact, glistening, doom shaped appearance. These cells have a high nuclear-to-cytoplasmic ratio with short cell cycle interval, grow more vigorously and are capable of undergoing successful differentiation both in vivo and vitro, and are considered to have high developmental potential and show naive status of porcine PSCs ${ }^{[29,49]}$. In general, morphology of stem cell represents a basic indicator for pluripotency of 
Table 4 Characteristics of porcine embryonic stem cells

\begin{tabular}{|c|c|c|c|c|c|c|c|c|c|c|c|c|}
\hline \multirow[b]{2}{*}{$\begin{array}{l}\text { Cell } \\
\text { sources }\end{array}$} & \multicolumn{4}{|c|}{ Morphology } & \multicolumn{3}{|c|}{ Pluripotent markers } & \multicolumn{2}{|c|}{ Differentiation in vivo } & \multicolumn{2}{|c|}{ Differentiation in vitro } & \multirow[b]{2}{*}{ Reference } \\
\hline & $\begin{array}{l}\text { Pluripotency } \\
\text { state }\end{array}$ & $\begin{array}{c}\text { Colony } \\
\text { formation } \\
\text { time/rate }\end{array}$ & Passage & Karyotype & $\begin{array}{l}\text { Pluripotency } \\
\text { factors }\end{array}$ & $\begin{array}{l}\text { Surface } \\
\text { markers }\end{array}$ & $\mathrm{AP}$ & Teratoma & Chimera & EB & $\begin{array}{c}\text { Multilineage } \\
\text { differentiation } \\
\text { potency }\end{array}$ & \\
\hline \multirow{3}{*}{$\begin{array}{l}\text { In vivo } \\
\text { and } \\
\text { in vitro } \\
\text { embryos }\end{array}$} & ESC-like & $10 \%$ & $p 14$ & Normal & $\begin{array}{c}O C T 4, \\
\text { NANOG }\end{array}$ & SSEA-1 & - & ND & $\mathrm{CP}$ & + & + & [114] \\
\hline & EpiSC-like & $5-7 d$ & $p>41$ & Normal & $\begin{array}{c}\text { OCT4, } \\
\text { NANOG, } \\
\text { SOX2, } \\
T D G F 1, R E X 1\end{array}$ & $\begin{array}{l}\text { SSEA4, } \\
\text { TRA-1-60, } \\
\text { TRA-1-81 }\end{array}$ & $\mathrm{AP}$ & - & ND & + & + & [29] \\
\hline & & $\begin{array}{l}1.6 \%- \\
9.5 \%\end{array}$ & $p \geqslant 9$ & Normal & $N A N O G$ & - & $\begin{array}{c}\mathrm{AP} \\
\text { (weak) }\end{array}$ & ND & ND & + & + & [115] \\
\hline \multirow[t]{3}{*}{$\begin{array}{l}\text { In vivo } \\
\text { embryos }\end{array}$} & ESC-like & $\begin{array}{l}>6 \mathrm{~d} \\
>43 \%\end{array}$ & ND & ND & $\begin{array}{l}\text { OCT4, } \\
\text { NANOG, } \\
\text { SOX2 }\end{array}$ & CK18 & AP & ND & ND & ND & + & [116] \\
\hline & EpiSC-like & $5-7 d$ & $p>12$ & Normal & $\begin{array}{c}\text { OCT4, } \\
\text { NANOG, } \\
\text { SOX2, } \\
\text { NODAL }\end{array}$ & SSEA-1 & - & ND & ND & + & + & [117] \\
\hline & & & & ND & $\begin{array}{c}O C T 4, \text { SOX } 2 \\
\text { NANOG }\end{array}$ & $\begin{array}{l}\text { TRA-1-60, } \\
\text { TRA-1-81 }\end{array}$ & AP & ND & ND & ND & ND & [33] \\
\hline \multirow[t]{11}{*}{$\begin{array}{l}\text { In vitro } \\
\text { embryos }\end{array}$} & ESC-like & $5-8 \mathrm{~d}$ & $p>48$ & Normal & $\begin{array}{c}\text { OCT4, } \\
\text { NANOG, } \\
\text { SOX2, REX-1 }\end{array}$ & $\begin{array}{l}\text { SSEA-1, } \\
\text { SSEA-4, } \\
\text { TRA-1-60, } \\
\text { TRA-1-81 }\end{array}$ & AP & - & ND & + & + & [118] \\
\hline & & $5.1 \%$ & $p \approx 100$ & Normal & $\begin{array}{c}\text { OCT4, } \\
\text { NANOG }\end{array}$ & $\begin{array}{l}\text { SSEA-1, } \\
\text { SSEA-4 }\end{array}$ & AP & ND & ND & ND & ND & [45] \\
\hline & & $8-13 \mathrm{~d}$ & $p>15$ & Normal & $\begin{array}{c}\text { OCT4, } \\
\text { NANOG }\end{array}$ & - & - & ND & $\mathrm{CB}$ & + & + & [119] \\
\hline & & ND & $p>50$ & Normal & $\begin{array}{c}\text { OCT4, KLF4, } \\
\text { STAT3, SOX2, } \\
\text { NANOG, } \\
\text { LIN28 }\end{array}$ & $\begin{array}{c}\text { SSEA-1 } \\
\text { (strong), } \\
\text { SSEA-4 } \\
\text { (weak) }\end{array}$ & AP & + & ND & ND & + & [46] \\
\hline & EpiSC-like & $39 \%$ & $p<52$ & Normal & $\begin{array}{c}\text { OCT3, OCT4, } \\
\text { NANOG }\end{array}$ & SSEA-4 & AP & + & ND & + & + & [120] \\
\hline & & $\begin{array}{c}5-8 \mathrm{~d} \\
>26.2 \%\end{array}$ & $p>25$ & Normal & $\begin{array}{c}\text { OCT4, } \\
N A N O G, \\
S O X 2, R E X-1\end{array}$ & - & AP & - & ND & + & + & [121] \\
\hline & & $17.6 \%$ & ND & ND & $\begin{array}{c}O C T 4, \text { SOX } 2 \\
\text { NANOG }\end{array}$ & - & AP & ND & ND & + & + & [122] \\
\hline & & $13-16 \mathrm{~d}$ & $p>75$ & Normal & $\begin{array}{c}O C T 4, \text { SOX2 } \\
\text { NANOG }\end{array}$ & - & AP & + & $\mathrm{CP}$ & + & + & [10] \\
\hline & & $10.7 \%$ & $p>90$ & Normal & OCT4 & $\begin{array}{l}\text { SSEA-4, } \\
\text { TRA-1-60, } \\
\text { TRA-1-81, }\end{array}$ & AP & + & ND & + & + & [123] \\
\hline & & $9 \mathrm{~d}$ & $p>36$ & Normal & $\begin{array}{c}O C T 4, \text { SOX2 } \\
\text { NANOG }\end{array}$ & - & AP & + & ND & + & + & [124] \\
\hline & ND & $<29 \%$ & ND & ND & $\begin{array}{c}\text { OCT4, } \\
\text { NANOG, } \\
\text { SOX2, } \\
\text { C-MYC }\end{array}$ & - & AP & ND & ND & ND & ND & [125] \\
\hline
\end{tabular}

Note: AP, alkaline phosphatase; EB, embryoid body; ND, not determined; $\mathrm{CP}$, chimeras piglets; $\mathrm{CB}$, chimeric blastocysts. 


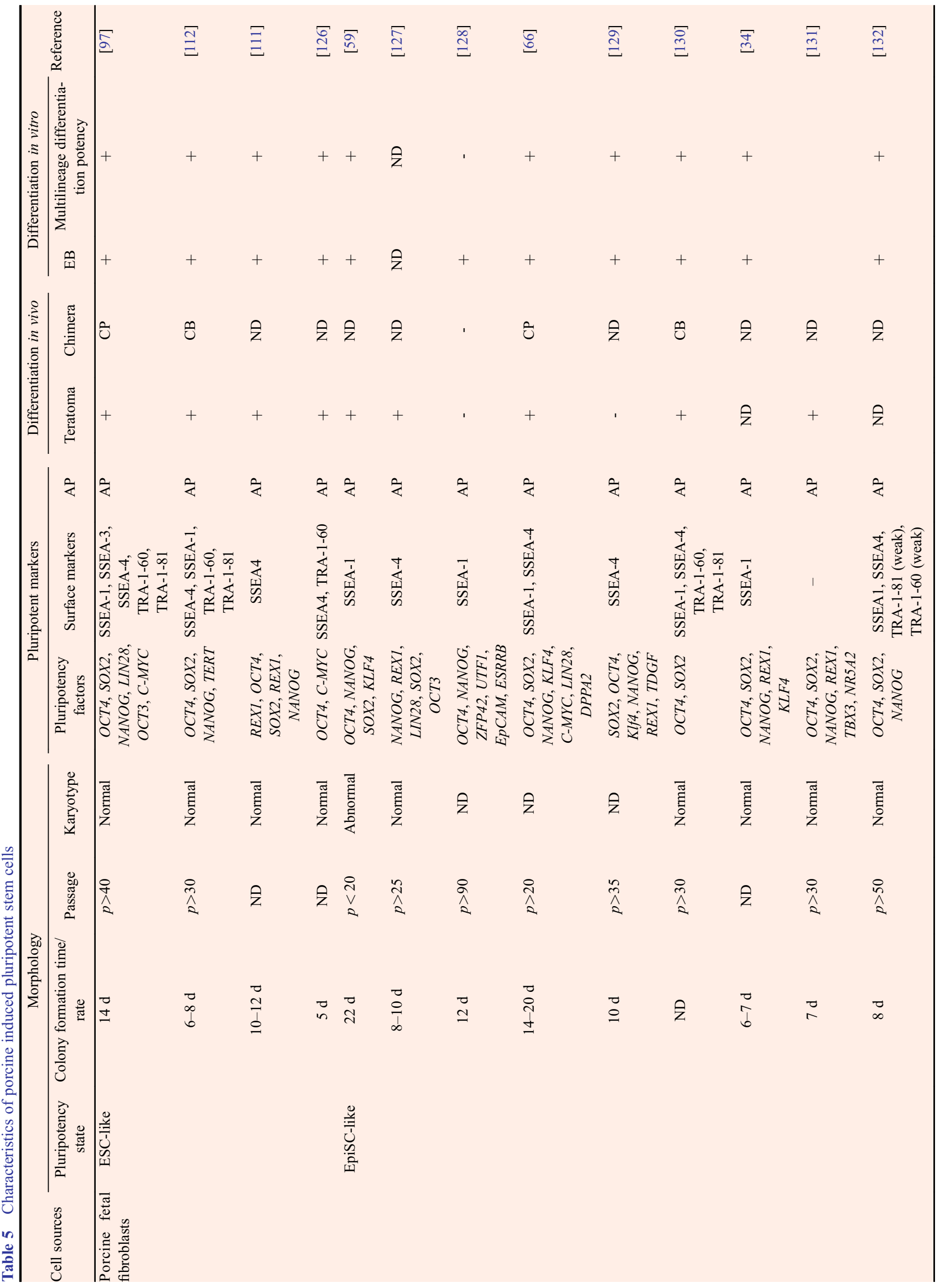




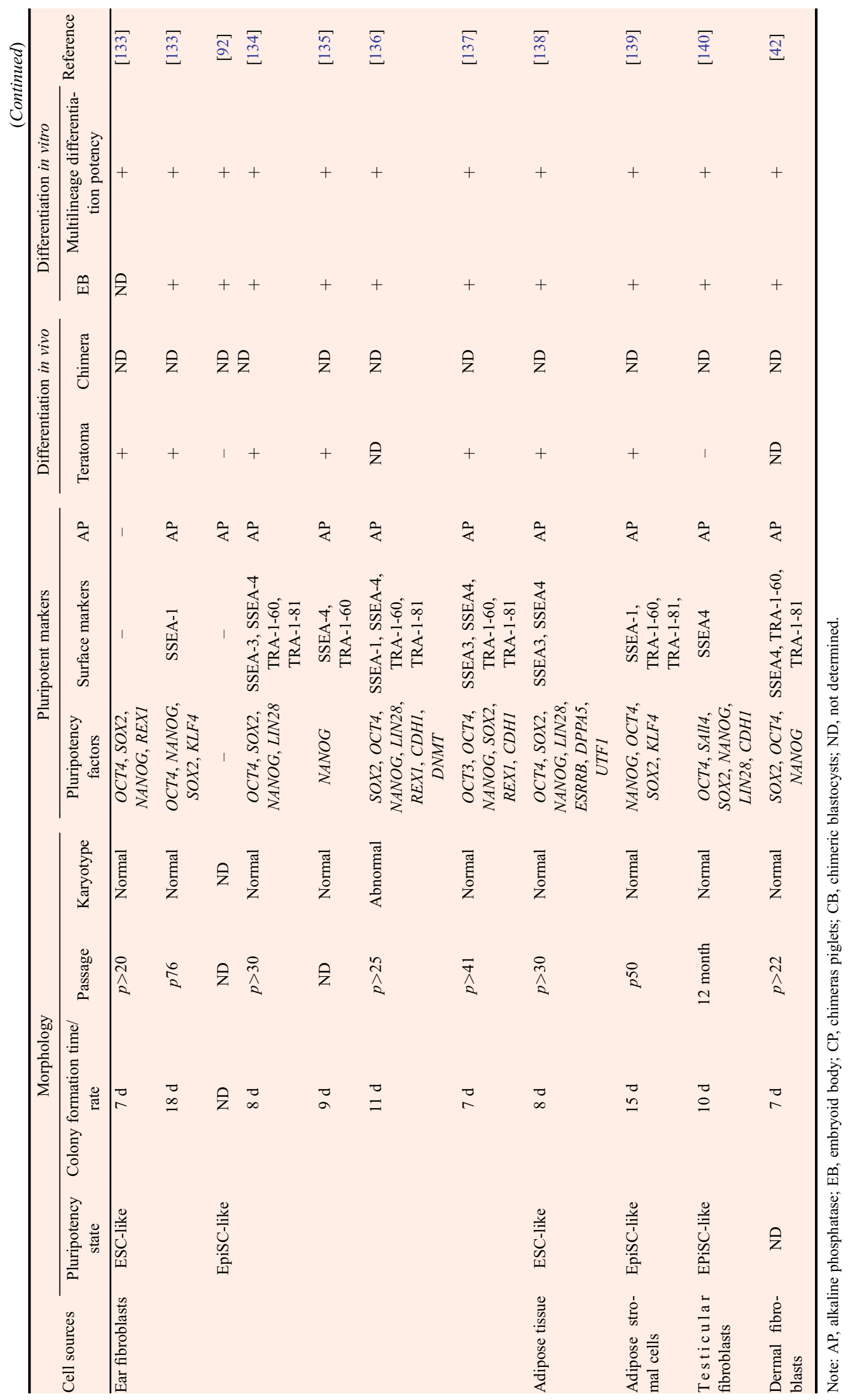


Table 6 Characteristics of porcine embryonic germ cells

\begin{tabular}{|c|c|c|c|c|c|c|c|c|c|c|c|c|}
\hline \multirow[b]{2}{*}{$\begin{array}{l}\text { Cell } \\
\text { sources }\end{array}$} & \multicolumn{4}{|c|}{ Morphology } & \multicolumn{3}{|c|}{ Pluripotent markers } & \multicolumn{2}{|c|}{ Differentiation in vivo } & \multicolumn{2}{|c|}{ Differentiation in vitro } & \multirow[b]{2}{*}{$\begin{array}{l}\text { Refer- } \\
\text { ence }\end{array}$} \\
\hline & $\begin{array}{c}\text { Pluripotency } \\
\text { state }\end{array}$ & $\begin{array}{l}\text { Colony forma- } \\
\text { tion time/rate }\end{array}$ & Passage & Karyotype & $\begin{array}{l}\text { Pluripotency } \\
\text { factors }\end{array}$ & $\begin{array}{l}\text { Surface } \\
\text { markers }\end{array}$ & $\overline{\mathrm{AP}}$ & Teratoma & $\begin{array}{l}\text { Chimera } \\
\text { formation }\end{array}$ & $\overline{\mathrm{EB}}$ & $\begin{array}{l}\text { Multilineage } \\
\text { differentiation } \\
\text { potency }\end{array}$ & \\
\hline \multirow{10}{*}{$\begin{array}{l}\text { Fetuses } \\
\text { (days 17- } \\
30 \text { ) }\end{array}$} & ESC-like & $7-10 \mathrm{~d}$ & $p 14$ & ND & - & - & $\mathrm{AP}$ & ND & $\overline{\mathrm{CP}}$ & + & ND & [41] \\
\hline & & $8 \mathrm{~d}$ & $p 54$ & Normal & OCT4 & $\begin{array}{l}\text { SSEA-4, } \\
\text { TRA-1-81, } \\
\text { SSEA-1 }\end{array}$ & $\mathrm{AP}$ & ND & ND & + & + & [141] \\
\hline & & $6-9 \mathrm{~d}$ & ND & ND & - & SSEA-1 & AP & ND & ND & + & Endoderm & [142] \\
\hline & & $6-9 \mathrm{~d}$ & ND & ND & - & SSEA-1 & $\mathrm{AP}$ & ND & ND & + & ND & [142] \\
\hline & & ND & $p \approx 35$ & ND & $\begin{array}{c}\text { OCT4, } \\
\text { SOX2, } \\
\text { NANOG, } \\
\text { REX1, } \\
\text { C-MYC }\end{array}$ & $\begin{array}{l}\text { SSEA-4, } \\
\text { TRA-1-60, } \\
\text { TRA-1-81 }\end{array}$ & AP & + & ND & + & + & [143] \\
\hline & & ND & $p 12$ & Normal & - & - & AP & ND & $\mathrm{CP}$ & + & + & [48] \\
\hline & & ND & $p 21-23$ & ND & - & - & AP & - & $\mathrm{CP}$ & + & + & [144] \\
\hline & & $5-7 \mathrm{~d}$ & $p>20$ & Normal & OCT4 & $\begin{array}{l}\text { SSEA-1 } \\
\text { (weak), } \\
\text { SSEA-3, } \\
\text { SSEA-4, }\end{array}$ & $\mathrm{AP}$ & + & ND & + & + & [145] \\
\hline & ND & $5-8 \mathrm{~d}$ & ND & ND & - & - & AP & ND & ND & ND & ND & [146] \\
\hline & ND & $7-10 \mathrm{~d}$ & $p>31$ & Normal & - & SSEA-1 & $\mathrm{AP}$ & ND & $\mathrm{CP}$ & ND & ND & [49] \\
\hline
\end{tabular}

Note: AP, alkaline phosphatase; EB, embryoid body; ND, not determined; $\mathrm{CP}$, chimeras piglets.

porcine stem cells. However, pPSCs with a hESC-like morphology were also reported to contribute to chimera formation $^{[10]}$.

\subsubsection{Colony formation and maintenance of pluripotency}

Authentic ESCs are able to self-renew and proliferate continuously in vitro with undifferentiated characteristics. Naive-state stem cells, like mouse ESCs, can be propagated after dissociation to single cells, however, this same treatment can rapidly damage porcine PSCs with colonies that need to be detached from the feeder layer and passaged mechanically. Therefore, colony formation rate and doubling time are important indicators of pluripotency in porcine PSCs. In fact, most studies focus on the primary colony formation time (7-10 $\mathrm{d}$ after being plated onto the feeder layer) or rate (percentage of established porcine PSCs from blastocysts) rather than the date of colony formation and doubling time of established pESC and EGC lines ${ }^{[45,46]}$. This gap in studies of porcine PSCs deserves serious attention because fast and steady proliferation and passage are important characters of PSCs.

\subsubsection{Karyotype analysis}

Karyotype analysis is important because PSCs, including porcine PSCs, with abnormal karyotype cannot be used for research. Giemsa banding is widely used for porcine PSCs because this method can produce a visible karyotype by staining condensed chromosomes. Most porcine PSCs are normal in karyotype (38 chromosomes), but a few porcine iPSCs have been found with abnormal chromosome numbers and karyotypic instability which occurred with increased numbers of passages ${ }^{[135]}$. Overall, considering the safety and clinical application of piPSCs, karyotype analysis might be an indispensable assay before clinical studies.

\subsection{Pluripotency markers}

\subsubsection{Pluripotency factors}

OCT4 is considered to be key for pluripotency because it is expressed specifically in the ICM of blastocyst and ESCs of mice and humans, and its expression ceases in the subsequently differentiated cells and tissues ${ }^{[15]}$. However, the expression pattern and regulation mechanism of OCT4 in porcine embryos or PSCs are quite different from those in mice ${ }^{[149,150]}$. The pluripotency factors, including of OCT4, REXI and KLF4, are still the main markers widely used in evaluating pluripotency of porcine PSCs (Tables $4-6$ ). In recent years, researchers have begun to realize the limitation of these factors for porcine PSCs and 
additional pluripotent factors have been identified to evaluate pluripotency of porcine PSCs, such as TDGF1, CK18, STAT3, LIN28 and C-MYC.

\subsubsection{Stem cell surface markers}

Stem cell surface markers, such as stage-specific embryonic antigen SSEA-1 (mouse ESC-specific), SSEA-3 and TRA-1-81 (human ESCs-specific), have been used to characterize both mouse and human PSCs ${ }^{[151]}$. However, ICM in porcine blastocysts cannot exclusively express the naive-state marker SSEA-1 ${ }^{[152]}$. Neither the blastocysts (D5/6) nor the epiblasts (D9/10) express any human ESCssurface markers, suggesting a precluded active state of pluripotency ${ }^{[153]}$. It is generally considered that porcine PSCs expressing SSEA-1 have a high developmental potential, however, porcine iPSCs have been shown to maintain pluripotency for more than 50 passages and contribute to chimera formation without the expression of SSEA-1 ${ }^{[42]}$. Thus, it is difficult to distinguish which PSCs lines possess a higher pluripotency by detecting stem cell surface markers.

\subsubsection{Alkaline phosphatase}

Alkaline phosphatase (AP) is the first molecule demonstrated to be a reliable marker for undifferentiated ESCs in pig $^{[154]}$ and some researchers use AP activity as the early detection marker during porcine iPSC establishment ${ }^{[137]}$. Porcine iPSCs and ESCs with weak AP activity have limited developmental potential and insufficient differentiation ability, suggesting that AP activity is not only an indicator of stem cells but also a potential evaluation marker for pluripotency in porcine stem cells ${ }^{[46,125,133]}$.

\subsection{X-chromosome activation}

The active X-chromosome (XaXa) state pluripotent cells are considered as naive-state stem cells and are capable of development into chimeras after injection into allogeneic embryos $^{[155]}$. Therefore, X-chromosome activation is considered to be a key indicator that a pluripotent cell is in a naive or primed state ${ }^{[155]}$. For porcine iPSCs, three cell lines generated by the expression of transcription factors OCT4, KLF4 and C-MYC showed naive-like iPSC properties with an activated $\mathrm{X}$-chromosome, as well as high embryonic chimera incorporation efficiency ${ }^{[97,126,130]}$. In addition, Haraguchi and colleagues successfully established a unique cell line derived from ICM of porcine embryo that exhibited LIF-dependency but not bFGFdependency, and could be considered as naive-state cells as mouse ESCs; however, the X-chromosome status in this cell line was $\mathrm{XaXi}^{[45]}$.

XIST is a dominant regulator gene of XCI used to monitor the X-chromosome activation status. However, the regulatory mechanisms and expression patterns in pigs are complicated and not well defined ${ }^{[156,157]}$. Also, many studies only determined PSCs to be in the naive state using the expression of XIST or H3K27me3 staining but did not test other capabilities, such as germline chimerism. Thus, application of evaluation X-chromosome activation in porcine PSCs will be limited until these problems have been solved.

\subsection{Differentiation ability of stem cell in vivo and in vitro}

\subsubsection{Teratoma}

The efficiency of teratoma formation in established porcine ESCs and EGCs lines was low for all teratoma detection reported for porcine PSC lines (Table 4; Table 6), which suggests that current culture systems cannot maintain the pluripotency of porcine PSCs. However, reprogramming somatic cells to a pluripotent state by the iPSC methods has demonstrated some level of success in teratoma formation (Table 5). The high teratoma formation rate found in porcine iPSCs may be because they can maintain their populations of undifferentiated cells by expressing oncogenes, which raises issues of the safety of application of piPSCs in clinical studies.

\subsubsection{Chimera assay}

High rates of production of chimeric blastocysts (up to $83.3 \%$ ) can be obtained through aggregation of blastomeres from early stage embryos with different genetic background and most of the cells will then undergo a further differentiation leading to the formation of trophoblastic cells. However, the efficiency of blastomere aggregation with porcine PSCs is very low (Tables 4-6). Most groups would opt to use early embryo injection and select the early morula without compaction for injection because of the collapse of blastocoels. However, porcine PSCs have been reported to produce chimeric animals based on the coat color and microsatellite examination, but no researchers have been able to obtain chimeras by germline transmission.

\subsubsection{Tetraploid complementation}

Tetraploid (4N) complementation is considered as a key evaluation criterion for detection of pluripotency in stem cells $^{[158,159]}$. Full term development of embryos from stem cells injected into the tetraploid embryos would prove the pluripotency of cells. Unfortunately, no studies have obtained viable piglets by tetraploid complementation using porcine ESCs, EGCs and iPSCs (Tables 4-6), which could be explained by the primed pluripotent state of pPSCs used. 


\subsubsection{Embryoid body formation}

Embryoid body formation (in vitro) is now routinely used to confirm pluripotency of stem cells. In porcine PSCs, embryoid bodies with a similar morphology to that described for mice were formed and they had three germ layer markers (endoderm, mesoderm, and ectoderm). However, the embryonic body generated from porcine EGCs is restricted to a simple embryoid body, not to a cystic form ${ }^{[142]}$.

\subsubsection{Multilineage differentiation potency}

In porcine ESCs and EGCs, most of the cell lines can differentiate into three embryonic germ layer cell types (Table 4; Table 6). In addition, porcine iPSCs have been coaxed to differentiate into several neuronal lineages ${ }^{[140]}$, cardio myocytes ${ }^{[132,134]}$ and even hepatocytes ${ }^{[160]}$. Such abilities of porcine PSCs to form different tissues are critical and will of benefit for future development of preclinical studies, but there are still many issues to be resolved before these cells can be used in a safe and reproducible manner.

\section{Challenges and prospects}

PSCs can differentiate into various tissues and organs in animals, which means they have been widely used in clinical research and breeding, and naive mouse ESCs not only propagate steadily in vitro but also perform tetraploid compensation and germline transmission ${ }^{[161]}$. However, defects still exist with PSC lines derived from large animals. At present, the embryonic stem cells of existing large animals have encountered similar problems. PSCs cannot be propagated stably in vitro for the long-term and PSCs are unable to produce teratoma and chimera animals although they have certain differentiation abilities $^{[10,45,118,162,163]}$.

Relative to the embryonic stem cell lines, studies on iPSCs in large animals has made more progress, especially for pigs. However, there are still some difficulties, cell propagation is dependent on exogenous genes and cannot produce germline chimeric offspring ${ }^{[59,127,130,164,165]}$. These problems need to be solved urgently for the study of PSCs in large animals. In addition, the establishment of naive PSCs in porcine and some other kinds of livestock has significant valuable for biomedical research and animal breeding.

\subsection{Generation of high quality pluripotent stem cells}

Over the last three decades, substantial efforts have been made to generate PSCs from livestock. Reasons for the poor research outcomes are not entirely clear and key questions remain surrounding the basic biology of PSCs, for example: what is the best embryonic stage for isolating pluripotent cells from porcine embryo; what are the pluripotent markers and signaling pathways that regulate pluripotency in pigs, and what are the optimal culture conditions for sustaining long-term in vitro culture of pESC lines? The solution to these problems will facilitate the establishment of $\mathrm{pESCs}^{[29,111,166]}$.

Unique regulatory signaling pathways may be associated with porcine ICM development. Mouse, human and pig embryos differ in co-expressed genes related to fatty acid metabolic processes, lipid metabolic processes, the biological aspects of the cytoplasm, nucleus, mitochondria and protein binding. Large numbers of lipids exist in the porcine early embryos and lipids supplement promotes mesenchymal-epithelial transition (MET) through the cAMP/PKA/CREB signal pathway and upregulates the E-cadherin expression during porcine somatic cell reprogramming. These findings may facilitate understanding of the lipid metabolism and lay the foundation for derivation of bona fide porcine embryonic stem cells ${ }^{[167]}$. MicroRNAs play a very important role in regulating reprogramming, pluripotency and cell fate decisions and hpiPSCs and mpiPSCs under different pluripotent states revealed significant differences in the miRNA signatures. These differentially expressed miRNAs may play important roles in pluripotent regulation in pigs.

Given the prospective advantages and current limitations, many researchers have recently emphasized the importance of establishing validated pESCs. It has been noted that defining the optimum stage of embryonic development for stem cell derivation and a clear understanding of key signaling pathways that regulate the pluripotency of pESCs, would be beneficial for obtaining stable pESC lines ${ }^{[17,168,169]}$.

\subsection{Porcine PSCs application in clinical medicine}

Given that pigs have immunological and physiological similarities to humans, a porcine model provides the ideal non-primate system for clinical research. Porcine PSCs are important for modeling embryonic development and disease processes in biomedical research, and they are especially important for transplantation medicine, immunology and the study of the circulatory system ${ }^{[3,170]}$.

Inactivation of porcine endogenous retroviruses opens the possibility of porcine-to-human xenotransplantation $^{[171]}$. Porcine iPSCs can differentiate into photoreceptors which can integrate into the damaged swine neural retina, laying a foundation for retinal stem cell transplantation $^{[172]}$. Porcine iPSC grafted into the myocardium can differentiate into vessel cells, which result in increased formation of new vessels in an infarcted heart. Direct intramyocardial injection of porcine iPSCs can improve left ventricular function in an immunosuppressed porcine AMI model ${ }^{[173]}$. Generation of functional hepatocytes 


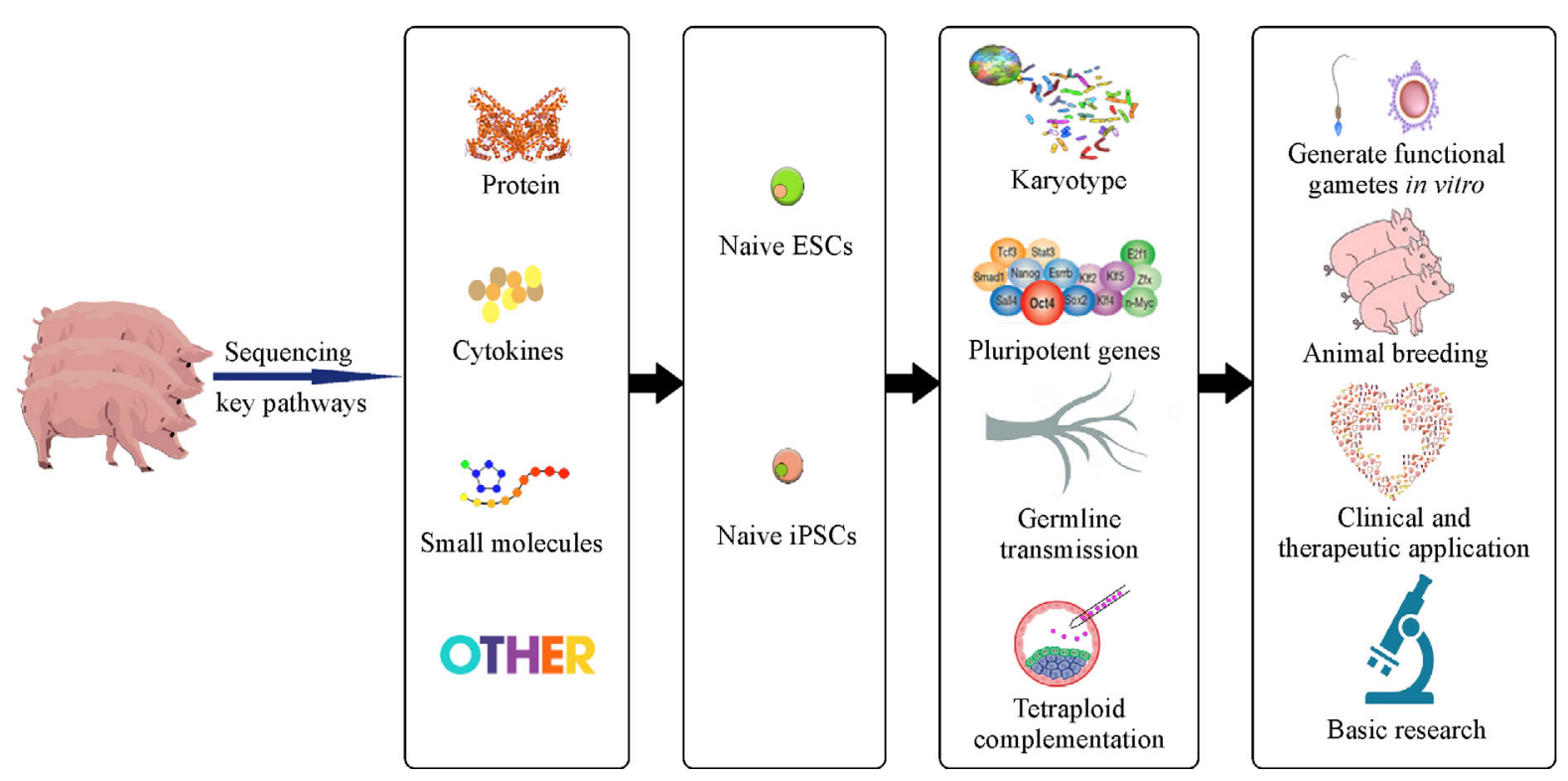

Fig. 2 Porcine embryonic stem cells have great significance and potential for wide application

from porcine iPSCs is considered to be a promising therapy for patients with liver diseases ${ }^{[174]}$, and robust neural differentiation from porcine iPSCs can fill the need for a powerful model to study autologous neural iPSCs therapies ${ }^{[140]}$. Moreover, insulin produced by pigs is widely used to treat diabetes, pig heart valves have been transplanted for over 50 years and skin transplants have been applied to human burn victims for over 30 years ${ }^{[175]}$. Transplantation of porcine hearts from $\alpha(1,3)$-galactosyltransferase knockout pigs has increased graft survival over previous methods ${ }^{[176]}$.Thus, establishment of pESCs provide a useful tool for future cell transplantation and for studying disease mechanisms.

\subsection{Porcine PSCs application in animal breeding}

For agricultural purposes, PSCs can serve as a valuable genetic engineering tool to improve the generation of livestock through introduction of advantageous genes that are important economically and in disease resistance traits. The potential benefits of transgenic livestock have been discussed and reviewed by many researchers over the past 20 years, but for the most part the promise has remained unfulfilled due to insufficient research effort ${ }^{[177]}$. As a substitute for $\mathrm{pESCs}$, porcine iPSCs were used to generate cloned animals using somatic cell nuclear transfer ${ }^{[178]}$, which is a valuable tool for generating transgenic animals. This suggests that application of PSCs in cloning might help reproduce a large number of endangered animals in the near future ${ }^{[179]}$, and perhaps new animal species can be obtained with heterologous chimeric technology.

In addition, PSCs have great potential to generate primordial germ cells capable of initiating meiosis and generating haploid gametes, oocyte and sperm ${ }^{[180]}$. The fertility of these in vitro-derived haploid gametes may produce viable and fertile offspring ${ }^{[181]}$. This would be of substantial value for finally achieving in vitro germ cell induction in domestic species and establishing a new animal breeding system to meet future meat and milk demand $^{[182,183]}$. In such a system, porcine and other larger animals' embryonic stem cells can be differentiated into oocyte and sperm. The oocyte and sperm can be fertilized in vitro, then embryos can be used to produce nextgeneration ESCs, or can be transferred into the uterus to produce live born. This laboratory animal breeding system would greatly shorten breeding time (Fig. 2).

In summary, although we have made a great deal of progress on mammalian pluripotency stem cells, significant problems still persist and many scientific issues need to be explored further.

Acknowledgements This work was funded by the National Key Research and Development Program of China-Stem Cell and Translational Research (2016YFA0100200).

Compliance with ethics guidelines Jianyong Han, Yi-Liang Miao, Jinlian Hua, Yan Li, Xue Zhang, Jilong Zhou, Na Li, Ying Zhang, Jinying Zhang, and Zhonghua Liu declare that they have no conflicts of interest or financial conflicts to disclose.

This article is a review and does not contain any studies with human or animal subjects performed by any of the authors.

\section{References}

1. Evans M J, Kaufman M H. Establishment in culture of pluripotential cells from mouse embryos. Nature, 1981, 292 (5819): 154-156 
2. Chambers I, Smith A. Self-renewal of teratocarcinoma and embryonic stem cells. Oncogene, 2004, 23(43): 7150-7160

3. Hall V. Porcine embryonic stem cells: a possible source for cell replacement therapy. Stem Cell Reviews and Reports, 2008, 4(4): 275-282

4. Liu S, Bou G, Sun R, Guo S, Xue B, Wei R, Cooney A J, Liu Z. Sox2 is the faithful marker for pluripotency in pig: evidence from embryonic studies. Developmental Dynamics, 2015, 244(4): 619627

5. Prelle K, Holtz W, Sborn M. The intermediate filament protein vimentin as differentiation marker in preimplantation porcine embryo. Biology of Reproduction, 1995, 52(S1): 177

6. Evans M J, Notarianni E, Laurie S, Moor R M. N E, Laurie S, Moor $\mathrm{R}$ M. Derivation and preliminary characterization of pluripotent cell lines from porcine and bovine blastocysts. Theriogenology, 1990, 33(1): 125-128

7. Piedrahita J A, Anderson G B, Bondurant R H. On the isolation of embryonic stem cells: comparative behavior of murine, porcine and ovine embryos. Theriogenology, 1990, 34(5): 879-901

8. Chen L R, Shiue Y L, Bertolini L, Medrano J F, BonDurant R H, Anderson G B. Establishment of pluripotent cell lines from porcine preimplantation embryos. Theriogenology, 1999, 52(2): 195-212

9. Li M, Ma W, Hou Y, Sun X F, Sun Q Y, Wang W H. Improved isolation and culture of embryonic stem cells from Chinese miniature pig. Journal of Reproduction and Development, 2004, 50(2): 237-244

10. Xue B, Li Y, He Y, Wei R, Sun R, Yin Z, Bou G, Liu Z. Porcine pluripotent stem cells derived from IVF Embryos contribute to chimeric development in vivo. PLoS One, 2016, 11(3): e0151737

11. Li M, Li Y H, Hou Y, Sun X F, Sun Q, Wang W H. Isolation and culture of pluripotent cells from in vitro produced porcine embryos. Zygote, 2004, 12(1): 43-48

12. Strojek R M, Reed M A, Hoover J L, Wagner T E. A method for cultivating morphologically undifferentiated embryonic stem cells from porcine blastocysts. Theriogenology, 1990, 33(4): 901-913

13. Magnani L, Cabot R A. In vitro and in vivo derived porcine embryos possess similar, but not identical, patterns of Oct4, Nanog, and Sox2 mRNA expression during cleavage development. Molecular Reproduction and Development, 2008, 75(12): 17261735

14. Brevini T A, Tosetti V, Crestan M, Antonini S, Gandolfi F. Derivation and characterization of pluripotent cell lines from pig embryos of different origins. Theriogenology, 2007, 67(1): 54-63

15. Kirchhof N, Carnwath J W, Lemme E, Anastassiadis K, Scholer H, Niemann H. Expression pattern of Oct-4 in preimplantation embryos of different species. Biology of Reproduction, 2000, 63 (6): 1698-1705

16. Kuijk E W, Du Puy L, Van Tol H T, Oei C H, Haagsman H P, Colenbrander B, Roelen B A. Differences in early lineage segregation between mammals. Developmental Dynamics, 2008, 237(4): 918-927

17. Vackova I, Ungrova A, Lopes F. Putative embryonic stem cell lines from pig embryos. Journal of Reproduction and Development, 2007, 53(6): 1137-1149

18. Shiue Y L, Yang J R, Liao Y J, Kuo T Y, Liao C H, Kang C H, Tai C, Anderson G B, Chen L R. Derivation of porcine pluripotent stem cells for biomedical research. Theriogenology, 2016, 86(1): 176-181

19. Bao S, Tang F, Li X, Hayashi K, Gillich A, Lao K, Surani M A. Epigenetic reversion of post-implantation epiblast to pluripotent embryonic stem cells. Nature, 2009, 461(7268): 1292-1295

20. Tosolini M, Jouneau A. From naive to primed pluripotency: in vitro conversion of mouse embryonic stem cells in epiblast Stem cells. Methods in Molecular Biology, 2016, 1341: 209-216

21. Yang Y, Liu B, Xu J, Wang J, Wu J, Shi C, Xu Y, Dong J, Wang C, Lai W, Zhu J, Xiong L, Zhu D, Li X, Yang W, Yamauchi T, Sugawara A, Li Z, Sun F, Li X, Li C, He A, Du Y, Wang T, Zhao C, Li H, Chi X, Zhang H, Liu Y, Li C, Duo S, Yin M, Shen H, Belmonte J C, Deng H. Derivation of pluripotent stem cells with in vivo embryonic and extraembryonic potency. Cell, 2017, 169(2): 243-257 e225

22. Yang J, Ryan D J, Wang W, Tsang J C, Lan G, Masaki H, Gao X, Antunes L, Yu Y, Zhu Z, Wang J, Kolodziejczyk A A, Campos L S, Wang C, Yang F, Zhong Z, Fu B, Eckersley-Maslin M A, Woods M, Tanaka Y, Chen X, Wilkinson A C, Bussell J, White J, Ramirez-Solis R, Reik W, Gottgens B, Teichmann S A, Tam P P L, Nakauchi H, Zou X, Lu L, Liu P. Establishment of mouse expanded potential stem cells. Nature, 2017, 550(7676): 393-397

23. Brevini T A, Pennarossa G, Gandolfi F. No shortcuts to pig embryonic stem cells. Theriogenology, 2010, 74(4): 544-550

24. Piedrahita J A, Anderson G B, Bondurant R H. Influence of feeder layer type on the efficiency of isolation of porcine embryo-derived cell lines. Theriogenology, 1990, 34(5): 865-877

25. Talbot N C, Rexroad C E Jr, Pursel V G, Powell A M, Nel N D. Culturing the epiblast cells of the pig blastocyst. In vitro Cellular \& Developmental Biology: Animal, 1993, 29(7): 543-554

26. Li M, Zhang D, Hou Y, Jiao L, Zheng X, Wang W H. Isolation and culture of embryonic stem cells from porcine blastocysts. Molecular Reproduction and Development, 2003, 65(4): 429-434

27. Brevini T, Cillo F, Gandolfi F. Establishment and molecular characterization of pig parthenogenetic embryonic stem cells. Reproduction, Fertility, and Development, 2005, 17(2): 235

28. Kim H S, Son H Y, Kim S, Lee G S, Park C H, Kang S K, Lee B C, Hwang W S, Lee C K. Isolation and initial culture of porcine inner cell masses derived from in vitro-produced blastocysts. Zygote, 2007, 15(1): 55-63

29. Park J K, Kim H S, Uh K J, Choi K H, Kim H M, Lee T, Yang B C, Kim H J, Ka H H, Kim H, Lee C K. Primed pluripotent cell lines derived from various embryonic origins and somatic cells in pig. PLoS One, 2013, 8(1): e52481

30. Vassiliev I, Vassilieva S, Beebe L F, McIlfatrick S M, Harrison S J, Nottle M B. Development of culture conditions for the isolation of pluripotent porcine embryonal outgrowths from in vitro produced and in vivo derived embryos. Journal of Reproduction and Development, 2010, 56(5): 546-551

31. Wang J, Wei R, Bou G, Liu Z. Tbx3 and Nr5 alpha2 improve the viability of porcine induced pluripotent stem cells after dissociation into single cells by inhibiting RHO-ROCK-MLC signaling. Biochemical and Biophysical Research Communications, 2015, 456(3): 743-749

32. Moore K, Piedrahita J A. The effects of human leukemia inhibitory factor (hLIF) and culture medium on in vitro differentiation of 
cultured porcine inner cell mass (pICM). In vitro Cellular \& Developmental Biology: Animal, 1997, 33(1): 62-71

33. Baek S, Han N R, Yun J I, Hwang J Y, Kim M, Park C K, Lee E, Lee $\mathrm{S} T$. Effects of culture dimensions on maintenance of porcine inner cell mass-derived cell self-renewal. Molecules and Cells, 2017, 40(2): 117-122

34. Wang J, Gu Q, Hao J, Jia Y, Xue B, Jin H, Ma J, Wei R, Hai T, Kong Q, Bou G, Xia P, Zhou Q, Wang L, Liu Z. Tbx3 and Nr5 alpha2 play important roles in pig pluripotent stem cells. Stem Cell Reviews and reports, 2013, 9(5): 700-708

35. Keefer C L, Pant D, Blomberg L, Talbot N C. Challenges and prospects for the establishment of embryonic stem cell lines of domesticated ungulates. Animal Reproduction Science, 2007, 98 (1-2): 147-168

36. Matsui Y, Zsebo K, Hogan B L. Derivation of pluripotential embryonic stem cells from murine primordial germ cells in culture. Cell, 1992, 70(5): 841-847

37. Vassiliev I, Vassilieva S, Beebe L F S, Harrison S J, Mcilfatrick S $\mathrm{M}$, Nottle $\mathrm{M}$ B. In vitro and in vivo characterization of putative porcine embryonic stem cells. Cellular Reprogramming, 2010, 12 (2): $223-230$

38. Shim H, Gutiérrezadán A, Chen L R, Bondurant R H, Behboodi E, Anderson G B. Isolation of pluripotent stem cells from cultured porcine primordial germ cells. Theriogenology, 1997, 47(5): 10891095

39. Shamblott M J, Axelman J, Wang S, Bugg E M, Littlefield J W, Donovan P J, Blumenthal P D, Huggins G R, Gearhart J D. Derivation of pluripotent stem cells from cultured human primordial germ cells. Proceedings of the National Academy of Sciences of the United States of America, 1998, 95(23): 1372613731

40. Hua J, Sidhu K. Recent advances in the derivation of germ cells from the embryonic stem cells. Stem Cells and Development, 2008, 17(3): 399-412

41. Piedrahita J A, Moore K, Oetama B, Lee C K, Scales N, Ramsoondar J, Bazer F W, Ott T. Generation of transgenic porcine chimeras using primordial germ cell-derived colonies. Biology of Reproduction, 1998, 58(5): 1321-1329

42. West F D, Terlouw S L, Kwon D J, Mumaw J L, Dhara S K, Hasneen K, Dobrinsky J R, Stice S L. Porcine induced pluripotent stem cells produce chimeric offspring. Stem Cells and Development, 2010, 19(8): 1211-1220

43. Hochereau-de Reviers M T, Perreau C. In vitro culture of embryonic disc cells from porcine blastocysts. Reproduction, Nutrition, Development, 1993, 33(5): 475-483

44. Hou P, Li Y, Zhang X, Liu C, Guan J, Li H, Zhao T, Ye J, Yang W, Liu K, Ge J, Xu J, Zhang Q, Zhao Y, Deng H. Pluripotent stem cells induced from mouse somatic cells by small-molecule compounds. Science, 2013, 341(6146): 651-654

45. Haraguchi S, Kikuchi K, Nakai M, Tokunaga T. Establishment of self-renewing porcine embryonic stem cell-like cells by signal inhibition. Journal of Reproduction and Development, 2012, 58 (6): 707-716

46. Telugu B P, Ezashi T, Sinha S, Alexenko A P, Spate L, Prather R S, Roberts R M. Leukemia inhibitory factor (LIF)-dependent, pluripotent stem cells established from inner cell mass of porcine embryos. Journal of Biological Chemistry, 2011, 286(33): 2894828953

47. Petkov S, Hyttel P, Niemann H. The small molecule inhibitors PD0325091 and CHIR99021 reduce expression of pluripotencyrelated genes in putative porcine induced pluripotent stem cells. Cellular Reprogramming, 2014, 16(4): 235-240

48. Shim H, Gutiérrez-Adán A, Chen L R, BonDurant R H, Behboodi E, Anderson G B. Isolation of pluripotent stem cells from cultured porcine primordial germ cells. Biology of Reproduction, 1997, 57 (5): 1089-1095

49. Mueller S, Prelle K, Rieger N, Petznek H, Lassnig C, Luksch U, Aigner B, Baetscher M, Wolf E, Mueller M, Brem G. Chimeric pigs following blastocyst injection of transgenic porcine primordial germ cells. Molecular Reproduction and Development, 1999, 54 (3): 244-254

50. Resnick J L, Bixler L S, Cheng L, Donovan P J. Long-term proliferation of mouse primordial germ cells in culture. Nature, 1992, 359(6395): 550-551

51. Baumann K. Stem cells: human primordial germ cells in a dish. Nature Reviews: Molecular Cell Biology, 2015, 16(2): 68

52. Labosky P A, Barlow D P, Hogan B L. Mouse embryonic germ (EG) cell lines: transmission through the germline and differences in the methylation imprint of insulin-like growth factor 2 receptor (Igf2r) gene compared with embryonic stem (ES) cell lines. Development, 1994, 120(11): 3197-3204

53. Kimura T, Kaga Y, Sekita Y, Fujikawa K, Nakatani T, Odamoto M, Funaki S, Ikawa M, Abe K, Nakano T. Pluripotent stem cells derived from mouse primordial germ cells by small molecule compounds. Stem Cells, 2015, 33(1): 45-55

54. López-Iglesias P, Alcaina Y, Tapia N, Sabour D, Arauzo-Bravo M J, Sainz de la Maza D, Berra E, O’Mara A N, Nistal M, Ortega S, Donovan P J, Schöler H R, De Miguel M P. Hypoxia induces pluripotency in primordial germ cells by HIF1 $\alpha$ stabilization and Oct4 deregulation. Antioxidants \& Redox Signalling, 2015, 22(3): 205-223

55. Bazley F A, Liu C F, Yuan X, Hao H, All A H, De Los Angeles A, Zambidis E T, Gearhart J D, Kerr C L. Direct reprogramming of human primordial germ cells into induced pluripotent stem cells: efficient generation of genetically engineered germ cells. Stem Cells and Development, 2015, 24(22): 2634-2648

56. Morohaku K, Hirao Y, Obata Y. Differentiation of mouse primordial germ cells into functional oocytes in vitro. Annals of Biomedical Engineering, 2017, 45(7): 1608-1619

57. Du X, Feng T, Yu D, Wu Y, Zou H, Ma S, Feng C, Huang Y, Ouyang $\mathrm{H}, \mathrm{Hu} \mathrm{X}$, Pan D, Li N, Wu S. Barriers for deriving transgene-free pig iPS cells with episomal vectors. Stem Cells, 2015, 33(11): 3228-3238

58. Gao Q S, Jin L, Li S, Zhu H Y, Guo Q, Li X C, Jin Q G, Kang J D, Yan C G, Yin X J. Generation of large pig and bovine blastocysts by culturing in human induced pluripotent stem cell medium. Zygote, 2016, 24(2): 236-244

59. Ezashi T, Telugu B P, Alexenko A P, Sachdev S, Sinha S, Roberts R M. Derivation of induced pluripotent stem cells from pig somatic cells. Proceedings of the National Academy of Sciences of the United States of America, 2009, 106(27): 10993-10998

60. Wu Y, Li O, He C, Li Y, Li M, Liu X L, Wang Y, He Y. Generation 
and characterization of induced pluripotent stem cells from guinea pig fetal fibroblasts. Molecular Medicine Reports, 2017, 15(6): 3690-3698

61. de Rooij D G, Russell L D. All you wanted to know about spermatogonia but were afraid to ask. Journal of Andrology, 2000, 21(6): 776-798

62. Meistrich M L. Effects of chemotherapy and radiotherapy on spermatogenesis. European Urology, 1993, 23(1): 136-142

63. Abbasi H, Hosseini S M, Hajian M, Nasiri Z, Bahadorani M, Tahmoorespur M, Nasiri M R, Nasr-Esfahani M H. Lentiviral vector-mediated transduction of goat undifferentiated spermatogonia. Animal Reproduction Science, 2015, 163: 10-17

64. Kanatsu-Shinohara M, Shinohara T. Spermatogonial stem cell selfrenewal and development. Annual Review of Cell and Developmental Biology, 2013, 29(1): 163-187

65. Kehler J, Tolkunova E, Koschorz B, Pesce M, Gentile L, Boiani M, Lomeli H, Nagy A, McLaughlin K J, Scholer H R, Tomilin A. Oct4 is required for primordial germ cell survival. EMBO Reports, 2004, 5(11): 1078-1083

66. Wu Y, Ouyang L, He C, Yong L, Min L, Liu X, Wang Y, He Y. Generation and characterization of induced pluripotent stem cells from guinea pig fetal fibroblasts. Molecular Medicine Reports, 2017, 15(6): 3690-3698

67. Zhang P, Chen X, Zheng Y, Zhu J, Qin Y, Lv Y, Zeng W. Longterm propagation of porcine undifferentiated spermatogonia. Stem Cells and Development, 2017, 26(15): 1121-1131

68. Kanatsu-Shinohara I, K Kanatsu-Shinohara M, Inoue K, Lee J, Yoshimoto M, Ogonuki N, Miki H, Baba S, Kato T, Kazuki Y, Toyokuni S, Toyoshima M, Niwa O, Oshimura M, Heike T, Nakahata T, Ishino F, Ogura A, Shinohara T. Generation of pluripotent stem cells from neonatal mouse testis. Cell, 2004, 119 (7): 1001-1012

69. Kossack N, Meneses J, Shefi S, Nguyen H N, Chavez S, Nicholas C, Gromoll J, Turek P J, Reijo-Pera R A. Isolation and characterization of pluripotent human spermatogonial stem cellderived cells. Stem Cells, 2009, 27(1): 138-149

70. Guan K, Wagner S, Unsold B, Maier L S, Kaiser D, Hemmerlein B, Nayernia K, Engel W, Hasenfuss G. Generation of functional cardiomyocytes from adult mouse spermatogonial stem cells. Circulation Research, 2007, 100(11): 1615-1625

71. Guan K, Wolf F, Becker A, Engel W, Nayernia K, Hasenfuss G. Isolation and cultivation of stem cells from adult mouse testes. Nature Protocols, 2009, 4(2): 143-154

72. Conrad S, Renninger M, Hennenlotter J, Wiesner T, Just L, Bonin M, Aicher W, Buhring H J, Mattheus U, Mack A, Wagner H J, Minger S, Matzkies M, Reppel M, Hescheler J, Sievert K D, Stenzl A, Skutella T. Generation of pluripotent stem cells from adult human testis. Nature, 2008, 456(7220): 344-349

73. Wu Q, Ohsako S, Ishimura R, Suzuki J S, Tohyama C. Exposure of mouse preimplantation embryos to 2,3,7,8-tetrachlorodibenzo-pdioxin (TCDD) alters the methylation status of imprinted genes H19 and Igf2. Biology of Reproduction, 2004, 70(6): 1790-1797

74. Kanatsu-Shinohara M, Inoue K, Lee J, Yoshimoto M, Ogonuki N, Miki H, Baba S, Kato T, Kazuki Y, Toyokuni S, Toyoshima M, Niwa O, Oshimura M, Heike T, Nakahata T, Ishino F, Ogura A, Shinohara T. Generation of pluripotent stem cells from neonatal mouse testis. Cell, 2004, 119(7): 1001-1012

75. Guo H, Hu B, Yan L, Yong J, Wu Y, Gao Y, Guo F, Hou Y, Fan X, Dong J, Wang X, Zhu X, Yan J, Wei Y, Jin H, Zhang W, Wen L, Tang F, Qiao J. DNA methylation and chromatin accessibility profiling of mouse and human fetal germ cells. Cell Research, 2017, 27(2): 165-183

76. Azizi H, Conrad S, Hinz U, Asgari B, Nanus D, Peterziel H, Hajizadeh Moghaddam A, Baharvand H, Skutella T. Derivation of pluripotent cells from mouse SSCs seems to be age dependent. Stem Cells International, 2016, 2016: 8216312

77. Ko K, Arauzo-Bravo M J, Kim J, Stehling M, Scholer H R. Conversion of adult mouse unipotent germline stem cells into pluripotent stem cells. Nature Protocols, 2010, 5(5): 921-928

78. Guan K, Nayernia K, Maier L S, Wagner S, Dressel R, Lee J H, Nolte J, Wolf F, Li M, Engel W, Hasenfuss G. Pluripotency of spermatogonial stem cells from adult mouse testis. Nature, 2006, 440(7088): 1199-1203

79. Bilousova G, Roop D R. Generation of functional multipotent keratinocytes from mouse induced pluripotent stem cells. Methods in Molecular Biology, 2013, 961: 337-350

80. Moraveji S F, Attari F, Shahverdi A, Sepehri H, Farrokhi A, Hassani S N, Fonoudi H, Aghdami N, Baharvand H. Inhibition of glycogen synthase kinase-3 promotes efficient derivation of pluripotent stem cells from neonatal mouse testis. Human Reproduction, 2012, 27(8): 2312-2324

81. Shen F J, Zhang C, Yang S X, Xiong Y H, Liao W B, Du X J, Wang L L. Long-term culture and identification of spermatogonial stem cells from BALB/c mice in vitro. National Journal of Andrology, 2008, 14(11): 977-981

82. Kanatsu-Shinohara M, Ogonuki N, Inoue K, Miki H, Ogura A, Toyokuni S, Shinohara T. Long-term proliferation in culture and germline transmission of mouse male germline stem cells. Biology of Reproduction, 2003, 69(2): 612-616

83. Zhang $\mathrm{C}, \mathrm{Wu}$ J. Production of offspring from a germline stem cell line derived from prepubertal ovaries of germline reporter mice. Molecular Human Reproduction, 2016, 22(7): 457-464

84. Zou K, Hou L, Sun K, Xie W, Wu J. Improved efficiency of female germline stem cell purification using fragilis-based magnetic bead sorting. Stem Cells and Development, 2011, 20(12): 2197-2204

85. Wang H, Jiang M, Bi H, Chen X, He L, Li X, Wu J. Conversion of female germline stem cells from neonatal and prepubertal mice into pluripotent stem cells. Journal of Molecular Cell Biology, 2014, 6 (2): 164-171

86. Takahashi K, Yamanaka S. Induction of pluripotent stem cells from mouse embryonic and adult fibroblast cultures by defined factors. Cell, 2006, 126(4): 663-676

87. Ezashi T, Telugu B P, Roberts R M. Induced pluripotent stem cells from pigs and other ungulate species: an alternative to embryonic stem cells? Reproduction in Domestic Animals, 2012, 47(Suppl 4): 92-97

88. Okita K, Yamanaka S. Induced pluripotent stem cells: opportunities and challenges. Philosophical Transactions of the Royal Society of London Series B: Biological Sciences, 2011, 366(1575): 2198-2207

89. Zhao X Y, Li W, Lv Z, Liu L, Tong M, Hai T, Hao J, Guo C, Ma Q, Wang L, Zeng F, Zhou Q. iPS cells produce viable mice through 
tetraploid complementation. Nature, 2009, 461(7260): 86-90

90. Liu J, Balehosur D, Murray B, Kelly J M, Sumer H, Verma P J. Generation and characterization of reprogrammed sheep induced pluripotent stem cells. Theriogenology, 2012, 77(2): 338-346 e331

91. Bao L, He L, Chen J, Wu Z, Liao J, Rao L, Ren J, Li H, Zhu H, Qian L, Gu Y, Dai H, Xu X, Zhou J, Wang W, Cui C, Xiao L. Reprogramming of ovine adult fibroblasts to pluripotency via drug-inducible expression of defined factors. Cell Research, 2011, 21(4): 600-608

92. Montserrat N, De Oñate L, Garreta E, Gonzãlez F, Adamo A, Eguizãbal C, Häfner S, Vassena R, Belmonte J C I. Generation of feeder-free pig induced pluripotent stem cells without Pou5f1. Cell Transplantation, 2012, 21(5): 815-825

93. Esteban M A, Peng M, Deli Z, Cai J, Yang J, Xu J, Lai L, Pei D. Porcine induced pluripotent stem cells may bridge the gap between mouse and human iPS. IUBMB Life, 2010, 62(4): 277-282

94. Han X, Han J, Ding F, Cao S, Lim S S, Dai Y, Zhang R, Zhang Y, Lim B, Li N. Generation of induced pluripotent stem cells from bovine embryonic fibroblast cells. Cell Research, 2011, 21(10): $1509-1512$

95. Huang B, Li T, Alonso-Gonzalez L, Gorre R, Keatley S, Green A, Turner P, Kallingappa P K, Verma V, Oback B. A virus-free polypromoter vector induces pluripotency in quiescent bovine cells under chemically defined conditions of dual kinase inhibition. PLoS One, 2011, 6(9): e24501

96. Song Z, Cai J, Liu Y, Zhao D, Yong J, Duo S, Song X, Guo Y, Zhao Y, Qin H, Yin X, Wu C, Che J, Lu S, Ding M, Deng H. Efficient generation of hepatocyte-like cells from human induced pluripotent stem cells. Cell Research, 2009, 19(11): 1233-1242

97. Fujishiro S H, Nakano K, Mizukami Y, Azami T, Arai Y, Matsunari H, Ishino R, Nishimura $\mathrm{T}$, Watanabe $\mathrm{M}$, Abe $\mathrm{T}$, Furukawa Y, Umeyama K, Yamanaka S, Ema M, Nagashima H, Hanazono Y. Generation of naive-like porcine-induced pluripotent stem cells capable of contributing to embryonic and fetal development. Stem Cells and Development, 2013, 22(3): 473-482

98. West F D, Uhl E W, Liu Y, Stowe H, Lu Y, Yu P, GallegosCardenas A, Pratt S L, Stice S L. Brief report: chimeric pigs produced from induced pluripotent stem cells demonstrate germline transmission and no evidence of tumor formation in young pigs. Stem Cells, 2011, 29(10): 1640-1643

99. Zhao T, Zhang Z N, Rong Z, Xu Y. Immunogenicity of induced pluripotent stem cells. Nature, 2011, 474(7350): 212-215

100. Okita K, Ichisaka T, Yamanaka S. Generation of germlinecompetent induced pluripotent stem cells. Nature, 2007, 448 (7151): 313-317

101. Park I H, Arora N, Huo H, Maherali N, Ahfeldt T, Shimamura A, Lensch M W, Cowan C, Hochedlinger K, Daley G Q. Diseasespecific induced pluripotent stem cells. Cell, 2008, 134(5): 877886

102. Wernig $M$, Meissner A, Foreman R, Brambrink $\mathrm{T}, \mathrm{Ku} \mathrm{M}$, Hochedlinger K, Bernstein B E, Jaenisch R. In vitro reprogramming of fibroblasts into a pluripotent ES-cell-like state. Nature, 2007, 448(7151): 318-324

103. Brambrink T, Foreman R, Welstead G G, Lengner C J, Wernig M, Suh H, Jaenisch R. Sequential expression of pluripotency markers during direct reprogramming of mouse somatic cells. Cell Stem
Cell, 2008, 2(2): 151-159

104. Okita K, Nakagawa M, Hyenjong H, Ichisaka T, Yamanaka S. Generation of mouse induced pluripotent stem cells without viral vectors. Science, 2008, 322(5903): 949-953

105. Yu J, Hu K, Smuga-Otto K, Tian S, Stewart R, Slukvin I I, Thomson J A. Human induced pluripotent stem cells free of vector and transgene sequences. Science, 2009, 324(5928): 797-801

106. Zhou H, Wu S, Joo J Y, Zhu S, Han D W, Lin T, Trauger S, Bien G, Yao S, Zhu Y, Siuzdak G, Scholer H R, Duan L, Ding S. Generation of induced pluripotent stem cells using recombinant proteins. Cell Stem Cell, 2009, 4(5): 381-384

107. Kim D, Kim C H, Moon J I, Chung Y G, Chang M Y, Han B S, Ko S, Yang E, Cha K Y, Lanza R, Kim K S. Generation of human induced pluripotent stem cells by direct delivery of reprogramming proteins. Cell Stem Cell, 2009, 4(6): 472-476

108. Li X, Liu D, Ma Y, Du X, Jing J, Wang L, Xie B, Sun D, Sun S, Jin X, Zhang X, Zhao T, Guan J, Yi Z, Lai W, Zheng P, Huang Z, Chang Y, Chai Z, Xu J, Deng H. Direct reprogramming of fibroblasts via a chemically induced XEN-like state. Cell Stem Cell, 2017, 21(2): 264-273

109. Zhao Y, Zhao T, Guan J, Zhang X, Fu Y, Ye J, Zhu J, Meng G, Ge J, Yang S, Cheng L, Du Y, Zhao C, Wang T, Su L, Yang W, Deng H. A XEN-like state bridges somatic cells to pluripotency during chemical reprogramming. Cell, 2015, 163(7): 1678-1691

110. Liu P, Chen M, Liu Y, Qi L S, Ding S. CRISPR-based chromatin remodeling of the endogenous Oct4 or Sox2 locus enables reprogramming to pluripotency. Cell Stem Cell, 2018, 22(2): 252-261

111. Liu Y, Ma Y, Yang J Y, Cheng D, Liu X, Ma X, West F D, Wang H. Comparative gene expression signature of pig, human and mouse induced pluripotent stem cell lines reveals insight into pig pluripotency gene networks. Stem Cell Reviews and Reports, 2014, 10(2): 162-176

112. Cheng D, Guo Y, Li Z, Liu Y, Gao X, Gao Y, Cheng X, Hu J, Wang H. Porcine induced pluripotent stem cells require LIF and maintain their developmental potential in early stage of embryos. PLoS One, 2012, 7(12): e51778

113. Hall V J, Christensen J, Gao Y, Schmidt M H, Hyttel P. Porcine pluripotency cell signaling develops from the inner cell mass to the epiblast during early development. Developmental Dynamics, 2009, 238(8): 2014-2024

114. Vassiliev I, Vassilieva S, Beebe L F, Harrison S J, McIlfatrick S M, Nottle M B. In vitro and in vivo characterization of putative porcine embryonic stem cells. Cellular Reprogramming, 2010, 12(2): 223230

115. Vackova I, Novakova Z, Krylov V, Okada K, Kott T, Fulka H, Motlik J. Analysis of marker expression in porcine cell lines derived from blastocysts produced in vitro and in vivo. Journal of Reproduction and Development, 2011, 57(5): 594-603

116. u Puy L, Chuva de Sousa Lopes S M, Haagsman H P, Roelen B A J. Analysis of co-expression of OCT4, NANOG and SOX2 in pluripotent cells of the porcine embryo, in vivo and in vitro. Theriogenology, 2011, 75(3): 513-526

117. Alberio R, Croxall N, Allegrucci C. Pig epiblast stem cells depend on activin/nodal signaling for pluripotency and self-renewal. Stem Cells and Development, 2010, 19(10): 1627-1636 
118. Kim S, Kim J H, Lee E, Jeong Y W, Hossein M S, Park S M, Park S W, Lee J Y, Jeong Y I, Kim H S, Kim Y W, Hyun S H, Hwang W S. Establishment and characterization of embryonic stem-like cells from porcine somatic cell nuclear transfer blastocysts. Zygote, 2010, 18(2): 93-101

119. Vassiliev I, Vassilieva S, Truong K P, Beebe L F, McIlfatrick S M, Harrison S J, Nottle M B. Isolation and in vitro characterization of putative porcine embryonic stem cells from cloned embryos treated with trichostatin A. Cellular Reprogramming, 2011, 13(3): 205213

120. Jung S K, Kim H J, Kim C L, Lee J H, You J Y, Lee E S, Lim J M, Yun S J, Song J Y, Cha S H. Enhancing effects of serum-rich and cytokine-supplemented culture conditions on developing blastocysts and deriving porcine parthenogenetic embryonic stem cells. Journal of Veterinary Science, 2014, 15(4): 519-528

121. Siriboon C, Lin Y H, Kere M, Chen C D, Chen L R, Chen C H, Tu C F, Lo N W, Ju J C. Putative porcine embryonic stem cell lines derived from aggregated four-celled cloned embryos produced by oocyte bisection cloning. PLoS One, 2015, 10(2): e0118165

122. Lee D K, Park C H, Choi K H, Jeong Y I, Uh K J, Hwang J Y, Lee S G, Lee C K. Aggregation of cloned embryos in empty zona pellucida improves derivation efficiency of pig ES-like cells. Zygote, 2016, 24(6): 909-917

123. Yang J R, Shiue Y L, Liao C H, Lin S Z, Chen L R. Establishment and characterization of novel porcine embryonic stem cell lines expressing hrGFP. Cloning and Stem Cells, 2009, 11(2): 235-244

124. Kim E, Hwang S U, Yoo H, Yoon J D, Jeon Y, Kim H, Jeung E B, Lee C K, Hyun S H. Putative embryonic stem cells derived from porcine cloned blastocysts using induced pluripotent stem cells as donors. Theriogenology, 2016, 85(4): 601-616

125. Tan G, Ren L, Huang Y, Tang X, Zhou Y, Li D, Song H, Ouyang $\mathrm{H}$, Pang D. Isolation and culture of embryonic stem-like cells from pig nuclear transfer blastocysts of different days. Zygote, 2012, 20 (4): 347-352

126. Gu Q, Hao J, Hai T, Wang J, Jia Y, Kong Q, Feng C, Xue B, Xie B, Liu S, Li J, He Y, Sun J, Liu L, Wang L, Liu Z, Zhou Q. Efficient generation of mouse ESCs-like pig induced pluripotent stem cells. Protein \& Cell, 2014, 5(5): 338-342

127. Esteban M A, Xu J, Yang J, Peng M, Qin D, Li W, Jiang Z, Chen J, Deng K, Zhong M, Cai J, Lai L, Pei D. Generation of induced pluripotent stem cell lines from Tibetan miniature pig. Journal of Biological Chemistry, 2009, 284(26): 17634-17640

128. Petkov S, Glage S, Nowak-Imialek M, Niemann H. Long-term culture of porcine induced pluripotent stem-like cells under feederfree conditions in the presence of histone deacetylase inhibitors. Stem Cells and Development, 2016, 25(5): 386-394

129. Park K M, Lee J, Hussein K H, Hong S H, Yang S R, Lee E, Woo H M. Generation of liver-specific TGF-alpha/c-Myc-overexpressing porcine induced pluripotent stem-like cells and blastocyst formation using nuclear transfer. Journal of Veterinary Medical Science, 2016, 78(4): 709-713

130. Zhang W, Pei Y, Zhong L, Wen B, Cao S, Han J. Pluripotent and metabolic features of two types of porcine iPSCs derived from defined mouse and human ES cell culture conditions. PLoS One, 2015, 10(4): e0124562

131. Liu Y, Yang J Y, Lu Y, Yu P, Dove C R, Hutcheson J M, Mumaw J
L, Stice S L, West F D. alpha-1,3-Galactosyltransferase knockout pig induced pluripotent stem cells: a cell source for the production of xenotransplant pigs. Cellular Reprogramming, 2013, 15(2): $107-116$

132. Bui H T, Kwon D N, Kang M H, Oh M H, Park M R, Park W J, Paik S S, Van Thuan N, Kim J H. Epigenetic reprogramming in somatic cells induced by extract from germinal vesicle stage pig oocytes. Development, 2012, 139(23): 4330-4340

133. Kwon D J, Jeon H, Oh K B, Ock S A, Im G S, Lee S S, Im S K, Lee J W, Oh S J, Park J K, Hwang S. Generation of leukemia inhibitory factor-dependent induced pluripotent stem cells from the Massachusetts General Hospital miniature pig. BioMed research international, 2013, 2013: 140639

134. ontserrat N, Bahima E G, Batlle L, Häfner S, Rodrigues A M C, González F, Belmonte J C I. Generation of pig iPS cells: a model for cell therapy. Journal of Cardiovascular Translational Research, 2011, 4(2): 121-130

135. Park K M, Cha S H, Ahn C, Woo H M. Generation of porcine induced pluripotent stem cells and evaluation of their major histocompatibility complex protein expression in vitro. Veterinary Research Communications, 2013, 37(4): 293-301

136. Wu Z, Chen J, Ren J, Bao L, Liao J, Cui C, Rao L, Li H, Gu Y, Dai $\mathrm{H}$, Zhu H, Teng X, Cheng L, Xiao L. Generation of pig induced pluripotent stem cells with a drug-inducible system. Journal of Molecular Cell Biology, 2009, 1(1): 46-54

137. Zhang Y, Wei C, Zhang P, Li X, Liu T, Pu Y, Li Y, Cao Z, Cao H, Liu Y, Zhang X, Zhang Y. Efficient reprogramming of naive-like induced pluripotent stem cells from porcine adipose-derived stem cells with a feeder-independent and serum-free system. PLoS One, 2014, 9(1): e85089

138. Gu M, Nguyen P K, Lee A S, Xu D, Hu S, Plews J R, Han L, Huber B C, Lee W H, Gong Y, de Almeida P E, Lyons J, Ikeno F, Pacharinsak C, Connolly A J, Gambhir S S, Robbins R C, Longaker M T, Wu J C. Microfluidic single-cell analysis shows that porcine induced pluripotent stem cell-derived endothelial cells improve myocardial function by paracrine activation. Circulation Research, 2012, 111(7): 882-893

139. Congras A, Barasc H, Canale-Tabet K, Plisson-Petit F, Delcros C, Feraud O, Oudrhiri N, Hadadi E, Griscelli F, Bennaceur-Griscelli A, Turhan A, Afanassieff M, Ferchaud S, Pinton A, YerleBouissou M, Acloque H. Non integrative strategy decreases chromosome instability and improves endogenous pluripotency genes reactivation in porcine induced pluripotent-like stem cells. Scientific Reports, 2016, 6(1): 27059

140. Yang J Y, Mumaw J L, Liu Y, Stice S L, West F D. SSEA4-positive pig induced pluripotent stem cells are primed for differentiation into neural cells. Cell Transplantation, 2013, 22(6): 945-959

141. Petkov S G, Anderson G B. Culture of porcine embryonic germ cells in serum-supplemented and serum-free conditions: the effects of serum and growth factors on primary and long-term culture. Cloning and Stem Cells, 2008, 10(2): 263-276

142. Lee C K, Piedrahita J A. Effects of growth factors and feeder cells on porcine primordial germ cells in vitro. Cloning, 2000, 2(4): 197-205

143. Petkov S G, Marks H, Klein T, Garcia R S, Gao Y, Stunnenberg H, Hyttel P. In vitro culture and characterization of putative porcine 
embryonic germ cells derived from domestic breeds and Yucatan mini pig embryos at Days 20-24 of gestation. Stem Cell Research, 2011, 6(3): 226-237

144. Rui R, Shim H, Moyer A L, Anderson D L, Penedo C T, Rowe J D, BonDurant R H, Anderson G B. Attempts to enhance production of porcine chimeras from embryonic germ cells and preimplantation embryos. Theriogenology, 2004, 61(7-8): 1225-1235

145. Tsung H C, Du Z W, Rui R, Li X L, Bao L P, Wu J, Bao S M, Yao $Z$. The culture and establishment of embryonic germ (EG) cell lines from Chinese mini swine. Cell Research, 2003, 13(3): 195-202

146. Durcova-Hills G, Prelle K, Muller S, Stojkovic M, Motlik J, Wolf E, Brem G. Primary culture of porcine PGCs requires LIF and porcine membrane-bound stem cell factor. Zygote, 1998, 6(3): 271-275

147. Kues W A, Herrmann D, Barg-Kues B, Haridoss S, NowakImialek M, Buchholz T, Streeck M, Grebe A, Grabundzija I, Merkert S, Martin U, Hall V J, Rasmussen M A, Ivics Z, Hyttel P, Niemann H. Derivation and characterization of sleeping beauty transposon-mediated porcine induced pluripotent stem cells. Stem Cells and Development, 2013, 22(1): 124-135

148. Li X, Shan Z Y, Wu Y S, Shen X H, Liu C J, Shen J L, Liu Z H, Lei L. Generation of neural progenitors from induced Bama miniature pig pluripotent cells. Reproduction, 2014, 147(1): 65-72

149. Vejlsted M, Du Y, Vajta G, Maddox-Hyttel P. Post-hatching development of the porcine and bovine embryo-defining criteria for expected development in vivo and in vitro. Theriogenology, 2006, 65(1): 153-165

150. Bou G, Liu S, Sun M, Zhu J, Xue B, Guo J, Zhao Y, Qu B, Weng $\mathrm{X}$, Wei Y, Lei L, Liu Z. CDX2 is essential for cell proliferation and polarity in porcine blastocysts. Development, 2017, 144(7): 12961306

151. Maherali N, Hochedlinger K. Guidelines and techniques for the generation of induced pluripotent stem cells. Cell Stem Cell, 2008, 3(6): 595-605

152. Hall V J, Jacobsen J V, Rasmussen M A, Hyttel P. Ultrastructural and molecular distinctions between the porcine inner cell mass and epiblast reveal unique pluripotent cell states. Developmental Dynamics, 2010, 239(11): 2911-2920

153. Hall V J, Hyttel P. Breaking down pluripotency in the porcine embryo reveals both a premature and reticent stem cell state in the inner cell mass and unique expression profiles of the naive and primed stem cell states. Stem Cells and Development, 2014, 23 (17): 2030-2045

154. Wianny F, Perreau C, Hochereau de Reviers M T. Proliferation and differentiation of porcine inner cell mass and epiblast in vitro. Biology of Reproduction, 1997, 57(4): 756-764

155. Nichols J, Smith A. Naive and primed pluripotent states. Cell Stem Cell, 2009, 4(6): 487-492

156. Park C H, Uh K J, Mulligan B P, Jeung E B, Hyun S H, Shin T, Ka $\mathrm{H}$, Lee C K. Analysis of imprinted gene expression in normal fertilized and uniparental preimplantation porcine embryos. PLoS One, 2011, 6(7): e22216

157. Hwang J Y, Oh J N, Park C H, Lee D K, Lee C K. Dosage compensation of $\mathrm{X}$-chromosome inactivation center-linked genes in porcine preimplantation embryos: non-chromosome-wide initiation of X-chromosome inactivation in blastocysts. Mechan- isms of Development, 2015, 138(Pt 3): 246-255

158. Zhao X Y, Li W, Lv Z, Liu L, Tong M, Hai T, Hao J, Guo C L, Ma Q W, Wang L, Zeng F, Zhou Q. iPS cells produce viable mice through tetraploid complementation. Nature, 2009, 461(7260): 8690

159. Kang L, Wang J, Zhang Y, Kou Z, Gao S. iPS cells can support full-term development of tetraploid blastocyst-complemented embryos. Cell Stem Cell, 2009, 5(2): 135-138

160. Aravalli R N, Cressman E N, Steer C J. Hepatic differentiation of porcine induced pluripotent stem cells in vitro. Veterinary Journal, 2012, 194(3): 369-374

161. Zhao Y, Yin X, Qin H, Zhu F, Liu H, Yang W, Zhang Q, Xiang C, Hou P, Song Z, Liu Y, Yong J, Zhang P, Cai J, Liu M, Li H, Li Y, Qu X, Cui K, Zhang W, Xiang T, Wu Y, Zhao Y, Liu C, Yu C, Yuan K, Lou J, Ding M, Deng H. Two supporting factors greatly improve the efficiency of human iPSC generation. Cell Stem Cell, 2008, 3(5): 475-479

162. Cong S, Cao G, Liu D. Effects of different feeder layers on culture of bovine embryonic stem cell-like cells in vitro. Cytotechnology, 2014, 66(6): 995-1005

163. Verma V, Huang B, Kallingappa P K, Oback B. Dual kinase inhibition promotes pluripotency in finite bovine embryonic cell lines. Stem Cells and Development, 2013, 22(11): 1728-1742

164. Gao Y, Guo Y, Duan A, Cheng D, Zhang S, Wang H. Optimization of culture conditions for maintaining porcine induced pluripotent stem cells. DNA and Cell Biology, 2014, 33(1): 1-11

165. Talluri T R, Kumar D, Glage S, Garrels W, Ivics Z, Debowski K, Behr R, Niemann H, Kues W A. Derivation and characterization of bovine induced pluripotent stem cells by transposon-mediated reprogramming. Cellular Reprogramming, 2015, 17(2): 131140

166. Fang R, Liu K, Zhao Y, Li H, Zhu D, Du Y, Xiang C, Li X, Liu H, Miao Z, Zhang X, Shi Y, Yang W, Xu J, Deng H. Generation of naive induced pluripotent stem cells from rhesus monkey fibroblasts. Cell Stem Cell, 2014, 15(4): 488-497

167. Zhang W, Wang H, Zhang S, Zhong L, Wang Y, Pei Y, Han J, Cao $\mathrm{S}$. Lipid supplement in the cultural condition facilitates the porcine iPSC derivation through cAMP/PKA/CREB signal pathway. International Journal of Molecular Sciences, 2018, 19(2): 509515

168. Muñoz M, Trigal B, Molina I, Diez C, Caamano J N, Gomez E. Constraints to progress in embryonic stem cells from domestic species. Stem Cell Reviews and Reports, 2009, 5(1): 6-9

169. Brevini T A, Antonini S, Cillo F, Crestan M, Gandolfi F. Porcine embryonic stem cells: facts, challenges and hopes. Theriogenology, 2007, 68(S1): S206-S213

170. Telugu B P, Ezashi T, Roberts R M. The promise of stem cell research in pigs and other ungulate species. Stem Cell Reviews and Reports, 2010, 6(1): 31-41

171. Yang L, Guell M, Niu D, George H, Lesha E, Grishin D, Aach J, Shrock E, Xu W, Poci J, Cortazio R, Wilkinson R A, Fishman J A, Church G. Genome-wide inactivation of porcine endogenous retroviruses (PERVs). Science, 2015, 350(6264): 1101-1104

172. Zhou L, Wang W, Liu Y, de Castro J F, Ezashi T, Telugu B P V L, Roberts R M, Kaplan H J, Dean D C. Differentiation of induced pluripotent stem cells of swine into rod photoreceptors and their 
integration into the retina. Stem Cells, 2011, 29(6): 972-980

173. Li X, Zhang F, Song G, Gu W, Chen M, Yang B, Li D, Wang D, Cao K. Intramyocardial injection of pig pluripotent stem cells improves left ventricular function and perfusion: a study in a porcine model of acute myocardial infarction. PLoS One, 2013, 8 (6): e66688

174. Ao Y, Mich-Basso J D, Lin B, Yang L. High efficient differentiation of functional hepatocytes from porcine induced pluripotent stem cells. PLoS One, 2014, 9(6): e100417

175. Schuurman H J, Pierson R N. Progress towards clinical xenotransplantation. Frontiers in Bioscience-Landmark, 2008, 13 (13): 204-220

176. Fujimura T, Takahagi Y, Shigehisa T, Nagashima H, Miyagawa S, Shirakura R, Murakami H. Production of alpha 1,3-galactosyltransferase gene-deficient pigs by somatic cell nuclear transfer: a novel selection method for gal alpha 1,3-Gal antigen-deficient cells. Molecular Reproduction and Development, 2008, 75(9): 1372-1378

177. Piedrahita J A, Olby N. Perspectives on transgenic livestock in agriculture and biomedicine: an update. Reproduction, Fertility, and Development, 2011, 23(1): 56-63

178. Fan N, Chen J, Shang Z, Dou H, Ji G, Zou Q, Wu L, He L, Wang F, Liu K, Liu N, Han J, Zhou Q, Pan D, Yang D, Zhao B, Ouyang Z, Liu Z, Zhao Y, Lin L, Zhong C, Wang Q, Wang S, Xu Y, Luan J, Liang Y, Yang Z, Li J, Lu C, Vajta G, Li Z, Ouyang H, Wang H,
Wang Y, Yang Y, Liu Z, Wei H, Luan Z, Esteban M A, Deng H, Yang H, Pei D, Li N, Pei G, Liu L, Du Y, Xiao L, Lai L. Piglets cloned from induced pluripotent stem cells. Cell Research, 2013, 23(1): 162-166

179. Blomberg L A, Telugu B P. Twenty years of embryonic stem cell research in farm animals. Reproduction in Domestic Animals, 2012, 47(S4): 80-85

180. Handel M A, Eppig J J, Schimenti J C. Applying "gold standards" to in-vitro-derived germ cells. Cell, 2014, 157(6): 1257-1261

181. Bui H T, Van Thuan N, Kwon D N, Choi Y J, Kang M H, Han J W, Kim T, Kim J H. Identification and characterization of putative stem cells in the adult pig ovary. Development, 2014, 141(11): 2235-2244

182. Hickey J M, Chiurugwi T, Mackay I, Powell W, Hickey J M, Chiurugwi T, Mackay I, Powell W, Eggen A, Kilian A, Jones C, Canales C, Grattapaglia D, Bassi F, Atlin G, Gorjanc G, Dawson I, Rabbi I, Ribaut J M, Rutkoski J, Benzie J, Lightner J, Mwacharo J, Parmentier J, Robbins K, Skot L, Wolfe M, Rouard M, Clark M, Amer P, Gardiner P, Hendre P, Mrode R, Sivasankar S, Rasmussen S, Groh S, Jackson V, Thomas W, Beyene Y. Genomic prediction unifies animal and plant breeding programs to form platforms for biological discovery. Nature Genetics, 2017, 49(9): 1297-1303

183. Zhang Y, Ma J, Li H, Lv J, Wei R, Cong Y, Liu Z. bFGF signalingmediated reprogramming of porcine primordial germ cells. Cell and Tissue Research, 2016, 364(2): 429-441 